\title{
NEW GEOLOGICAL, PALAEOBOTANICAL AND PALYNOLOGICAL EVIDENCE OF THE CARBONIFEROUS FROM BRANDOV (KRUŠNÉ HORY MTS., CZECH REPUBLIC)
}

\author{
Zbyněk Šimůnek $^{1 *}$, Bedřich Mlčoch ${ }^{1}$ and Jana Drábková ${ }^{1}$
}

${ }^{1}$ Czech Geological Survey, Klárov 3/131, 11821 Praha 1, Czech Republic. *Corresponding author: zbynek.simunek@geology.cz

\begin{abstract}
Gas-pipeline construction around Brandov (Czech Republic) exposed pre Quaternary strata allowing more precise understanding of the regional geology. The crystalline rocks in the basement, near the Brandov Carboniferous Relict, belong to Sayda Dome rather than to the Hora Svaté Kateriny (Katharinaberg) Dome. The lower Carboniferous unit (Westphalian-Moscovian) is of greater extent than previously estimated. In contrast, the upper unit, which is correlated with Stephanian (Kasimovian or Gzhelian) strata, is arealy less extensive than previously estimated and is devoid of fossil remains. An anthracite seam, in the lower unit, was discovered in the "North depth" some 1-1.3 km to the North from old mining activity of the "South depth". The seam was accompanied by a flora dominated by cordaitaleans and sphenopsids (calamitaleans), and common lycopsids and ferns. Palynomorphs were isolated from mudstones for the first time and 36 genera and 51 species of miospores could be determined. A humic clayey layer was discovered in the Quaternary deposits whose palynological age is 500 - 100 years old.
\end{abstract}

Key words: Westphalian, Brandov Carboniferous relict, flora, palynoflora, geology

\section{INTRODUCTION}

Interest in the "Brandov Basin" renewed during the construction of the gas-pipeline "Gazela" in 2010-2012. Fossiliferous Carboniferous rocks and an anthracite coal seam were discover in the "North depth", which occurs in the northern part of the "Brandov Basin" separated by submerged crystalline ridge from the "South depth". Plant fossils and palynological samples were obtained for the first time. Though palynological assemblages have been obtained from both the pipeline trench in the "North depth" and from the tailings of the "Glück auf" mine in the "South depth"; they are impoverish. This study is the first palynological study conducted on samples from the "Brandov Basin".

In this study we use "Brandov Carboniferous" for a small remnant block of sediment that remained from a much larger sedimentary basin, which is now tectonically separated from other crystalline rocks. The Brandov Carboniferous were deposited unconformably on Precambrian lower Paleozoic (?) crystalline rock. In older literature the "Brandov Carboniferous" has had several names: Brandov (Anthracite) Basin (Němejc,
1930, 1953), Krušné hory (Erzgebirge) Carboniferous, Brandov Relict (Havlena, 1964), Upper Palaeozoic occurrences in Krušné hory, Occurrence near Brandov (Pešek et al., 2001), and Brandov-Olbernhau Basin (Hofman et al., 2012). It is clear that "basin" is not an appropriate term for this small relict, and suggested is the name Brandov Carboniferous Relict ("Brandov C.R." used herein), or Brandov Carboniferous Occurrence.

\section{MATERIAL AND METHODS}

Palaeobotanical samples were collected in the three localities along the trench for gas the pipeline "Gazela": Br 1 (N: 50 38.1'; E: $\left.13^{\circ} 23.687^{\prime}\right)$, Br 2 $\left(\mathrm{N}: 50^{\circ} 38.213^{\prime}\right.$; E: $\left.13^{\circ} 23.593^{\prime}\right)$ and $\mathrm{Br} 3\left(\mathrm{~N}: 50^{\circ}\right.$ 38.26'; E: $13^{\circ} 23.53^{\prime}$ ), and they are stored in the Czech Geological Survey, Prague. The figured samples have numbers ZŠ 392, 393, 394 and ZŠ 551 through ZŠ 558. The unfigured samples, mostly Cordaites sp. and Calamites sp. have numbers ZS 559 through 584.

$\mathrm{Br} 1$ locality was the only locality in which it was possible to study the section and collect fos- 
sils from individual layers in situ. The rest of the flora was obtained from the berm material that has since been put back in the trench to cover the pipeline and is no longer accessible.

Seven samples from carbonaceous claystones, siltstones and bright coal were processed to obtain palynomorphs. Two Br 1 samples are from beneath the coal (Plate 1, Figs 4, 5). Five samples (coal, dark grey claystones and siltstones) were collected at an old spoil pile of the "Glück auf" mine. Palynomorphs were isolated from the rocks using standard technique (Batten in Jones and Rowe, 1999). Ten palynological glycerine-jelly slides were made from each sample. Slides, digital images and samples are stored in the Czech Geological Survey, Prague. Spores were compared according to the system of classification suggested by Potonié and Kremp (1954, 1955a, b), Dettmann (1963) and Smith and Butterworth (1967). Percentage proportion of palynomorphs was not stated due to poor preservation.

\section{MINING HISTORY, STRATIGRAPHY AND GEOLOGY}

The Brandov C.R. is a small basin $(3.5 \mathrm{~km}$ long and $1.5 \mathrm{~km}$ wide), situated on the northern slope of the Krušné hory (Erzgebirge) Mountains, near Hora Svaté Kateřiny (Katharinaberg) in Bohemia. This basin is well-known for its anthracite seams that have been mined for nearly 100 years (Cílek, 1964). The coal discovery was made in 1825 , mining began a year later. In 1924 the mines were abandoned after 700,000 t anthracite had been removed from the ground. Mining stopped due to inflation in Germany. The documents that held the history of this mining district have subsequently been lost in a fire. A geological overview and coal history was published by Purkyně (1926, 1930), who elaborated on the results of earlier research by various authors (Ernst von Warnsdorf, 1853; Cotta, 1854; Feismantel, 1873; Pošepný,1926; Zelenka, 1926). Later papers deal with basin stratigraphy (Havlena, 1964; Pešek, et al., 2001; Spudil, 1998). Mlčoch et al., (1991) placed crystalline basement rocks into the Precambrian Sayda Dome complex.

Although mining activity started in the Brandov C.R. in the $1^{\text {st }}$ half of the $19^{\text {th }}$ century, plant fossils were not reported until Cotta (1854) reported many finds of Sigillaria homotaxially demonstrating the Carboniferous age of the sediment. Geinitz (1856) classified "Brandov Carboniferous" to his "Sigillaria coal zone" and so did Jokély (1857). Feistmantel, O. (1873) grouped the upper Brandov coals seams with the red deposits (Permian) immediately overlying the coal, while his father Feistmantel, K. (1883) correlated the Brandov coals with the Upper Radnice coal (Carboniferous). Thuma (1920) published Sterzel's floral list and indicated that the flora was Westphalian in age. Němejc (1930) undertook a comprehensive revision of Brandov flora and correlated it with the Moscovian (Westphalian C) Radnice flora. Němejc (1953) revised the Sigillaria from the Brandov coal seams. Using this revision Němejc correlated the Brandov material with the Bashkirian (Upper Westphalian A) Žaclér coal seams. There are other taxa in the flora which must be considered when correlating a flora to any time scale. When these taxa are taken into account, Pešek et al., (2001) correlated the Brandov coal seams as Bolsovian (Westphalian C).

The aim of borehole and geophysical prospecting in 1957 was to verify total anthracite reserves and determine mining feasibility Cílek (1965). Slánský \& Valín (1962) focussed on clay-mineral layers in rhyolitic tuffs. Pipeline construction in 1992 and 2010-2012 added significantly to the geologicaly of the area most notably increasing greatly the extent Carboniferous units (Malík J. et al., 2011).

\section{Crystalline basement}

A gas pump station was built on the muscovite gneiss of the Sayda Dome complex (Mlčoch et al., 1991) and are exposed below the Carboniferous strata along the northern and western margin. The basement complex here was formerly thought to be part of the Hora Svaté Kateřiny (Reitzenheim-Catharinaberg) Dome (Zelenka, 1926).

An altered serpentinite complex was exposed, in the pipline trench at the unconformity between the basement and the Brandov C.R. at its SE. margin (Figure 1). The serpentinites were previously unknown as the area is overlain by Quaternary colluvial deposits. This body lies in continuation of serpentinite body near Zöblitz and is connected with smaller serpentinite bodies on the German side of the Svídnice valley. 


\section{Carboniferous (Westphalian)}

The Carboniferous (Westphalian) sequence (Lower unit of Pešek et al., 2001; Brandov Formation of Hofman et al., 2012), of the Brandov C.R. is formed of conglomerates, sandstones, mudstones clays and coal (anthracite) seams. Conglomerates dominate with mudstones making up the remainder of the sediments in the lower part of the section. Upward from the conglomerate the proportion of mudstone layers increases and four coal cycles are preserved (Pešek et $a l ., 2001)$. The maximum thickness of the Carboniferous is estimated to be $250 \mathrm{~m}$. Coal seams heretofore known and mined only in the southern part of the Brandov C.R. in the "South depth", are now know to be present in the pipeline trench in the "North depth".

During the winter months 2011-2012, 2.2 $\mathrm{km}$. open pipeline trench ran from the pump station bisecting a line between Brandov village and state boundary (Figure 1), and through the whole northeastern part of the Brandov C.R. The Carboniferous rocks exposed in the trench included $0.8 \mathrm{~km}$ of Westphalian and $0.95 \mathrm{~km}$ of Stephanian rocks. The remainder of the trench exposed circa $0.45 \mathrm{~km}$ of Quaternary colluvial deposits.



Figure 1. Geological chart of the Brandov Basin. 1 - Stephanian; 2 - Horizon of rhyolite tuff intercalations; 3 - Westphalian; 4 - Muscovite \pm garnet gneisses; 5 - Altered serpentinite; 6 - Fine-grained paragneiss (4, 5, 6 - Sayda Dome); 7 - Faults; 8 - Trench for gaspipeline Gazela in 2012 and 2000; 9 - Boreholes; 10 - Documentation point; 11 - Contour lines (25 m); 12 - Road; 13 - Creek; 14 - State border; 15 - Gas-pipe-station.

The naturally exposed Carboniferous strata in the study area are all Westphalian sandstones, coaly sandstones, mudstones, claystones and a $1 \mathrm{~m}$ thick coal (anthracite) seam. It is now possible to 
project the existence of Carboniferous strata under the Quaternary deposits along the northeastern margin of the basin with a greater areal extent than previously know. Carboniferous strata extends from the pipeline to Svídnice Creek but is not exposed at the surface due to the thick Quaternary deposits unconformably overlaying them.

\section{Carboniferous (Stephanian)}

The upper sequence (Upper unit of Pešek et al., 2001; Olbernhau Formation of Hofman et al., 2012) has an erosional contact with the Westphalian strata, itself up to $100 \mathrm{~m}$ thick (Purkyně, 1930; Cílek, 1965). This Upper unit is formed by conglomerates, sandstones and mudstones.

The Carboniferous conglomerates are composed primarily cobbles of the basement rock, however there are much less common clasts of rhyolite (Cílek, 1965). Cílek (1965) subdivided the strata into three units pre-tuffite, tuffite and post-tuffite. The "tuffite horizon" consists mainly of grey or pinkish fine-grained tuffaceous sandstones with sporadic layers of limestones. The sandstones contain a large component of clay. The sand-sized components contain bipyramidal quartz crystals, orthoclase grains and hexagonal laminas of biotite among others. The thin layers of illite-montmorillonite claystones (Slánský \& Valín, 1962) represent reworked weathered rhyolite tuffs. Valín (1970) mentioned $18 \mathrm{~m}$ of rhyolite tuffs and tuffites. Zelenka (1926) indicated that the tuffite extended to the northwest, based on small surface outcrops and manmade exposures. He described argillaceous and arkose tuffite and glass porphyry in this unite.

A sequence of reworked rhyolite tuffs and lapilli tuffs, were documented in the northern margin of the basin by the excavation for pipeline excavation in the years 1992 (location point NV 362) and 2010 (NV 389) (Figure 1). These occurrences of acid volcanic tuffs are further North than earlier supposed in the "north depth" (Purkyně, 1929). Acid volcanic tuffs were not recognized in the "North depth" by Zelenka (1926). Laminated tuff beds several $\mathrm{cm}$ to tens $\mathrm{cm}$ thick (Figure 2) dip $10-15^{\circ}$ west were observed, below the Quartenary gravels, in the $4 \mathrm{~m}$ deep trench on the right side (east) of the Načetín Creek. Total thickness of the rhyolite tuffs is not know. As exposed in the bottom of the trench it is more than $1 \mathrm{~m}$.

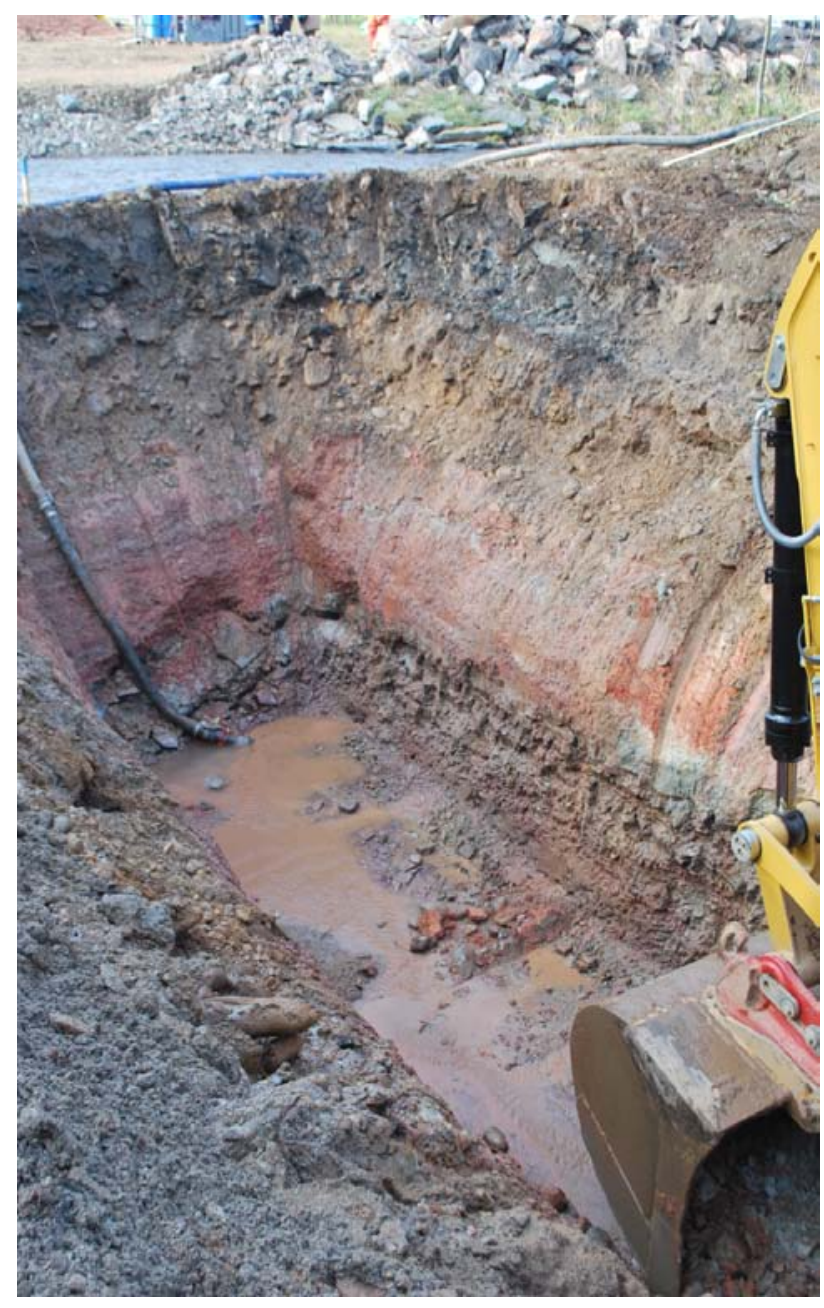

Figure 2. Trench for pipeline near the Czech side of the Svidnice creek. Fine-grained bedded tuffs lie beneath the alterated Stephanian clays and Holocene fluvial gravels (NV 389). Photo B. Mlčoch.

Microscopically, a sample from NV 389, is very fine-grained tuff and contains rare fragments of quartz and biotite. Finely laminated tuff, a sample from NV 388, consists of quartz fragments (up to $0.5 \mathrm{~mm}$ ), flakes of biotite (up to $0.7 \mathrm{~mm}$ ), muscovite and small lithic fragments of crystalline rocks, (up to $0.5 \mathrm{~mm}$ ) enclosed in a fine-grained matrix (Figure 3). The quartz fragments are angular to subangular (explosive fragmentation, excluding transport by water) with great variability in size. The poor sorting supports deposition near the source vent. Platy fragments and crystals have a strongly preferred orientation ) that suggests pyroclastic surge deposition. Field and laboratory measurements of this tuff are given in the Table 1. 
Table 1. Value of natural radioactve elements and magnetic susceptibility

\begin{tabular}{|c|c|c|c|c|c|c|c|c|c|c|c|c|c|}
\hline \multirow[b]{2}{*}{ lokality } & \multirow[b]{2}{*}{ rock } & \multirow[b]{2}{*}{ point } & \multicolumn{4}{|c|}{ field measurement } & \multicolumn{7}{|c|}{ laboratory measurement } \\
\hline & & & $\mathbf{K} \%$ & eU ppm & eTh ppm & kappa & Th & $\mathbf{U}$ & $\mathbf{e U}$ & $\mathbf{K}$ & Do & Dm & por. \\
\hline $\begin{array}{l}\text { Brandov } \\
\text { near cemetery }\end{array}$ & tuff & NV388 & 3.2 & 7.18 & 23.52 & $\begin{array}{l}1.48 ; 2.17 ; 0.06 ; \\
2.26 ; 2.28 ; 0.07\end{array}$ & 19.8 & 3.7 & 3.7 & 1.78 & 2.35 & 2.628 & 10.59 \\
\hline $\begin{array}{l}\text { Brandov } \\
\text { near cemetery }\end{array}$ & tuff & NV388 & 3.4 & 4.65 & 25.63 & & & & & & & & \\
\hline $\begin{array}{l}\text { Brandov } \\
\text { near cemetery }\end{array}$ & tuff & NV388B & 2.93 & 4.94 & 16.25 & $0.03 ; 0.15 ; 0.07$ & & & & & & & \\
\hline $\begin{array}{l}\text { Brandov } \\
\text { Načetín creek }\end{array}$ & $\begin{array}{c}\text { bedded } \\
\text { tuff }\end{array}$ & NV389 & & & & & & & & & 2.427 & 2.567 & V.42 \\
\hline
\end{tabular}

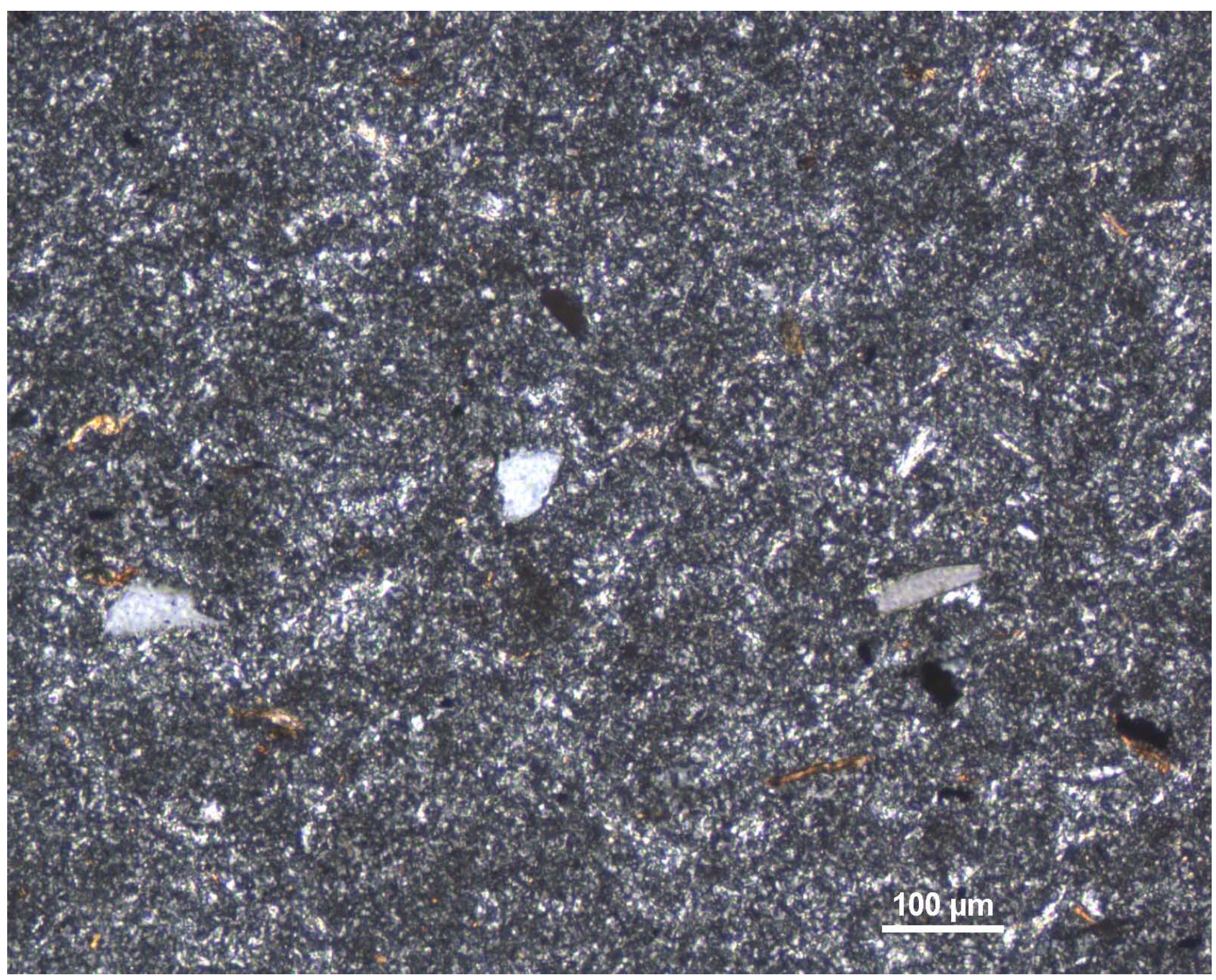

Figure 3. Microphotograph showing finely-bedded tuff that consists of fragments of quartz (up to $0.5 \mathrm{~mm}$ ), flakes of biotite (up to $0.7 \mathrm{~mm}$ ), muscovite and small lithic fragments (crystalline rocks, up to $0.5 \mathrm{~mm}$ ) enclosed in fine-grained matrix. Photo B. Mlčoch. 
The recently recognized extent of rhyolite pyroclastics is shown on the geological map "Erzgebirge/Vogtland" 1:100,000 (Hoth et al., 1995), which covers both Czech and German sides of the basin. (here Figure 1).

The biostratigraphic age of these deposits is not know as they are unfossiliferous. Feistmantel, O. (1873) suggested a Permian (Saxonian) age. Hofman et al. (2012) dated zircons from the pyroclastic rocks in the Olbernhau Formation ("Olbernhau Basin") in Germany (Schneider \& Romer, 2010), which are equivalents of the "Permian" rocks of the Brandov C.R. They stated the age as $302.6 \pm 2.8$ $\mathrm{Ma}$ and came to the conclusion that these rocks are younger than the Teplice Rhyolite body. Note that taking the standard deviation of $\pm 2.8 \mathrm{Ma}$ into account the strata could be Stephanian (upper part of the Kasimovian) or be wholly Gzhelian.

\section{Quaternary}

A one meter thick layer of grey clays probably of limnic origin (Holocene) was found below the colluvial deposits (locality NV D, see Figure 1), at the foot of crystalline elevation on the German side between the villages Rothenthal and Grünthal. Twelve spaced $5 \mathrm{~cm}$ thick bulk samples were collected from the $60 \mathrm{~cm}$ thick humic clayey layer at $2.5-3.1 \mathrm{~m}$ below the surface. The sediment ranges from 500 - 100 years old was determined palynologicaly by Břízová in Malík et al. (2011).

\section{PALAEOBOTANY}

Systematics (According to Cleal \& Thomas, 1995)

Class Lycopsida (club-mosses)

Order LEPIDOCARPALES Thomas et BrackHanes, 1984

Cyperites sp. (Plate II, Fig. 5) (specimen ZŠ 553, locality $\mathrm{Br} 1$, name Brandov)

1930 Sigillaria sp. - Leaves. Němejc. pl. 5, fig. 11. Fragments of 15 leaves found on two slabs, one of which is just similar to Němejc (1930, pl. 5, fig. 11). The biggest leaf fragment is $75 \mathrm{~mm}$ long. All leaves are only $2-3 \mathrm{~mm}$ wide with a prominent central vein. A specimen bear strongly marked lines along the midrib (stomatal grooves?).
Remark: This provisional genus reserved for the sterile, long (grass-like), pointed apex, enlarged and thickened at the base leaves of arborescent lycopsids. They belong predominantly to Sigillaria, but also to Lepidodendron, Asolanus and possibly to other stems.

Cf. Lepidostrobus sp. (Plate II, Fig. 1) (specimen ZŠ 551 locality Br 1, name Brandov)

$\mathrm{S}$ fragment $35 \mathrm{~mm}$ long and $10 \mathrm{~mm}$ wide has been found. The sharp distal parts of sporophylls are visible. Maybe this cone is of the Flemingites-type.

Class EQUISETOPSIDA (horsetails)

Order EQUISETALES Trevisan, 1876

Family CALAMOSTACHYACEAE Meyen, 1978

Calamites cf. carinatus Sternberg, 1823. (Plate II, Fig. 3) (specimen ZŠ 392 locality Br 1, name Brandov)

1823 Calamites carinatus Sternberg. pp. 36, 39, pl. 32 , fig. 1.

1825 Calamites carinatus Sternberg. Tentamen, p. XXVII.

1930 Calamites carinatus Sternberg. Němejc p. 48, 92, pl. 4, figs $6,7$.

1966 Calamites carinatus Sternberg. Crookall, p. $682-686$. pl. 129 , figs 2,3 , pl. 131, figs $1-3$, pl. 132, fig. 5, text-figs 200, 201.

Description: The fragment is $140 \mathrm{~mm}$ long and $>60 \mathrm{~mm}$ wide (at the node), as the specimen is damaged and full width is not known. The single twig scar (hole) is elliptical and large $-12 \mathrm{~mm}$ in diameter. The ribs are deformed around this hole in the circle of $40 \mathrm{~mm}$, and are relatively wide $1.5-2.5 \mathrm{~mm}$.

Calamites cf. cistii Brongniart, 1828. (Plate II, Fig. 4) (specimen ZŠ 393 locality Br 3, name Brandov)

1828 Calamites Cistii Brongniart, p. 129, pl. 20, figs $1-5$.

1930 Calamites Cisti Brongniart. Němejc, p. 48, 93, pl. 4, fig. 9 .

1966 Calamites Cistii Brongniart. Crookall, p. 639641. pl. 123 fig. 1, text-fig. 183.

Description: The imprint of axis fragment is 170 $\mathrm{mm}$ long and $40 \mathrm{~mm}$ wide. The ribs are fine and separated by shallow furrows, and together (a rib and furrow) are commonly $1 \mathrm{~mm}$ wide, or a little less. The nodes are not very prominent (three of 
them are preserved on the sample). The internode lengths are about $45 \mathrm{~mm}$.

Remark: This species differs from other Calamites species by very narrow ribs. The described specimen resembles the specimen figured by Němejc (1930) on pl. 4, fig. 9. However, Němejc's specimens have internodes $68 \mathrm{~mm}$ long.

Calamites cf. suckowii Brongniart, 1828. (Plate II, Fig. 2) (specimen ZŠ 552 locality $\mathrm{Br}$ 1, name Brandov)

1828 Calamites Suckowi Brongniart, p. 124, pl. 15 , figs 5,6 , pl. 16, fig. 2 , (non pl. 14, fig. 6 , pl. 15, fig. 1 and pl. 16, fig. 1).

1930 Calamtes aff. C. suckowi Brongniart. Němejc, p. 47, 92, pl. 3, fig. 4 .

1966 Calamites suckowi Brongniart. Crookall. p. $632-639$, pl. 119, figs $1-4$, pl. 120 , figs $1-3$, pl. 121 , fig. 1 , pl. 123 , fig. 2 , text-figs 181 , 182.

Description: Only a small axis fragment with one node has been found. The ribs wide - around $2 \mathrm{~mm}$, rounded at top and bottom, separated by narrow furrows. Tubercles at upper ends of ribs are oval or circular. The fragment is $70 \mathrm{~mm}$ long and $>30 \mathrm{~mm}$ wide (damaged specimen).

Remark: The rounded ends of ribs are typical for this species.

Calamites schuetzeiformis Kidston et Jongmans, 1917. (Plate III, Fig. 1) (specimen ZŠ 394 locality dump of the Glück auf coal mine, name Brandov)

1917 Calamites Schützeiformis Kidston et Jongmans, pp. 90, 92

1930 Calamits sp. Němejc, p. 91, pl. 4, fig. 10.

1966 Calamites schützeiformis Kidston and Jongmans. Crookall, p. 660, Text-fig. 194.

Description: This specimen was found on a dump of the coal mine in Brandov. It represents a calamite axis fragment $27 \mathrm{~cm}$ long and $45-47 \mathrm{~mm}$ wide. Internode lengths vary between 10-22 mm. Ribs are straight, generally prominent, in many cases not alternating in the nodes. Nodes are usually contracted. Tubercles at top of ribs are obscure. The ribs are 1-1.3 mm wide.

Remark: Němejc's (1930 pl. 4, fig. 10) specimen probably belongs to this species. It has also contracted nodes and short internodes, 5-10 mm long, shorter than in our sample, but it fits to the 4-90 $\mathrm{mm}$ range given by Crookall (1966).
Undeterminable Calamites remains (specimens: ZŠ 559, 562 through 564; 579 through 581; 583, locality $\mathrm{Br} .1, \mathrm{Br} 2, \mathrm{Br} 3$, name Brandov)

Asterophyllites cf. longifolius (Sternberg, 1825) Brongniart, 1828. (Plate II, Fig. 2) (specimen ZŠ 554, locality Br 1, name Brandov)

1825 Bruckmania longifolia Sternberg, Tentamen, p. XXIX, pl. 57, fig. 1 .

1828a Asterophyllites longifolia Sternberg. Brongniart 'Prodrome', pp. 159, 176.

1930 Asterophyllites longifolius Sternberg. Němejc, 49, 94, pl. 4, figs 1 and 2 .

1966 Asterophyllites longifolius Sternberg sp. forma typica Crookall, p. 704-707, pl. 150, fig. 2, pl. 140, fig. 2 (forma rigida Weiss pro sp.), text-fig. 205.

Description: Only one twig fragment with several nodes was found. Internodes are clear, but leaves are obscure. The internodes are $20-22 \mathrm{~mm}$ long and about $9 \mathrm{~mm}$ wide. 10-12 low relief ribs are present at the internode.

Remark: Němejc (1930) described this species from the Brandov C.R. with comparable dimensions. Though leafless and thus problematic, we are comfortable with the assignment of this specimen to Asterophyllites longifolius.

Class FILICOPSIDA (ferns)

Order BOTRYOPTERIDALES Meyen, 1987

Family TEDELEACEAE Eggert et Taylor, 1966

Senftenbergia plumosa (Artis, 1825) Stur 1885. (Plate III, Figs 3, 4) (specimen ZŠ 555, locality $\mathrm{Br} 3$, name Brandov)

1825 Filicites plumosus Artis, p. 17, pl. 17.

1832 Pecopteris plumosa Artis. Brongniart, p. 348, pl. 121, figs 1-2, pl. 122, figs 1-4.

1885 Senftenbergia plumosa (Artis). Stur, p. 9296, pl. 51, figs 1-3.

2003 Senftenbergia plumosa (Artis) Stur. Bek et Pšenička, p. 301-306, pl. 1-4.

Description: A sterile penultimate pinna fragment is $80 \mathrm{~mm}$ long and $35 \mathrm{~mm}$ at its widest. Preserved ultimate pinnae are 18-22 $\mathrm{mm}$ long and 6-7 $\mathrm{mm}$ wide. The pinnules are triangular, attached to the ultimate rachis by the whole basis. They are 4-6 $\mathrm{mm}$ long and 1.5 to $2 \mathrm{~mm}$ wide with entire, sinusoidal or slightly lobed pinnule margins. The midvein extends to the apex; single veins terminate to the margin teeth or lobes. 
Remarks: Senftenbergia plumosa is easily recognisable by its short triangular pinnules. Sterzel's floral list for Brandov C.R. includes this taxa (Thuma, 1920). However, Němejc (1930) was unable to locate the specimen either in the collections at the National Museum in Prague, nor in the Museum in Chemnitz. Lacking additional material of this taxa he thought that it was a misidentified. New material assignable to Senftenbergia plumosa has been recovered from the pipeline trench in the "North depth".

In the artificial system of fern-like foliage "Pteridophylla", the name Pecopteris plumosa is often used. Bek and Pšenička (2003) prefer using the name Senftenbergia plumosa based on its fructification. Additionally, the genus Pecopteris Brongniart usually contains genera and species of the family Marattiaceae, whereas Senftenbergia belongs only to the family Tedeleaceae.

Class PINOPSIDA

Order CORDAITANTHALES (cordaitaleans)

Family CORDAITANTHACEAE Meyen, 1984

Cordaites sp. (Plate III, Fig 5, 6; Plate IV, Figs 1, 3) (specimen ZŠ 560, 561; 566 through $571 ; 573$ trrough 578; 582, localities $\mathrm{Br} 1, \mathrm{Br} 2$ and $\mathrm{Br} 3$, name Brandov)

Němejc (1930) found only incomplete leaves in the collections of Chemnitz Museum and the National Museum in Prague. Based on the venation with two "sclerenchymatous strips" alternating with a true vein, asigned the Brandov specimens to the most common species Cordaites principalis (Germar) Geinitz. However, as with the new material, lack of the base and apex of the leaf it is impossible to make specific determinations. Therefore, none of the cordaitalean specimens can be classified beyond Cordaites sp.

Artisia cf. approximata Lindley et Hutton, 1837. (Plate II, Fig. 2) (specimen ZŠ 558, locality Br 1, name Brandov)

1828 Sternbergia approximata Brongniart 'Prodrome', p. 137 (nomen nudum)

1837 Sternbergia approximata Brongniart. Lindley et Hutton pl. 224, pl. 225

1838 Artisia approximata Brongniart. Corda in Sternbereg, p. 22, pl. 53, figs 1-6.

1970 Artisia approximata Lindley and Hutton. Crookall, p. 819-820, pl. 155, fig. 11, text-fig. 234A.
Description: Pith casts $90 \mathrm{~mm}$ long and $25 \mathrm{~mm}$ wide. Alternating horizontal constrictions and ridges are visible on the surface. The constrictions are very narrow and shallow; the ridges are usually $1.5-2.5 \mathrm{~mm}$ wide.

\section{EVALUATION}

\section{Brandov 1 ( $\mathrm{Br} 1)$}

Plant fossils were collected from several layers. Most of floral remains were obtained from friable claystones below the coal seam. A nearly monotypic cordaitalean assemblage was preserved here (Plate I, Fig. 5). Although the claystones were full of cordaitalean leaves only fragments could be obtained. Below this layer, is a four $\mathrm{cm}$ thick layer of silty sandstones (Plate I, Fig. 4). Plant axes, twigs and small stems occur in the base of this layer, they are usually poorly preserved, decorticated, and difficult to identify. They contain pith casts (and axis fragments) - Calamites sp. and Artisia cf. A. approximata. From the debris removed from the trench specimens of cordaitalean leaves and calamitaleans (Calamites sp. and Calamites cf. C. suckowii Brongniart) have been recovered. A specimen of indeterminate lycopsid remains (?Lepidostrobus sp. and ?Cyperites sp.) probably comes from the roof of the coal.

\section{Brandov 2 (Br 2)}

Only cordaitalean leaves (Cordaites sp.) in mudstones and a sphenopsid pith cast Calamites sp. in sandy siltstone were obtained.

\section{Brandov 3 (Br 3)}

This locality represents an approximately $50 \mathrm{~m}$ long section of trench. The material from the trench was a pile of black and grey sand and clay debris (Plate I, Fig. 1). Pith casts and axis fragments of sphenopsids (Calamites sp. and Calamites cf. C. cistii Brongniart) have been obtained from sandy rocks. Grey claystones and siltstones were poorly fossilioferous. Cordaitalean leaf were dominant, rare sphenopsid axis [Asterophyllites cf. A. longifolius (Sternberg) Brongniart] and the fern Senftenbergia plumosa (Artis) Stur have also been recovered. Questionable fragments of arborescent lycopsids (Cyperites sp.) have been obtained. Roots penetrating mudstones are seen penetrating the bedding. Charcoal is present on some bedding surfaces. 
Table 2. Distribution of palynomorphs in the Brandov C. R.

\begin{tabular}{|c|c|c|}
\hline \multirow{2}{*}{ TAXA } & \multicolumn{2}{|c|}{ Locality } \\
\hline & Br 1 & Gl \\
\hline Leiotriletes adnatoides Potonié et Kremp, 1955 & o & o \\
\hline Leiotriletes cf. convexus (Kosanke) Potonié et Kremp, 1955 & & o \\
\hline Leiotriletes minutus (Knox) Potonié et Kremp, 1955 & o & o \\
\hline Leiotriletes subadnatoides Bhardwaj, 1957 & & o \\
\hline Leiotriletes sphaerotriangulus (Loose) Potonié et Kremp, 1954 & o & o \\
\hline Leiotriletes gulaferus Potonié et Kremp, 1955 & o & o \\
\hline Leiotriletes tumidus Butterworth et Williams, 1958 & & o \\
\hline Leiotriletes sp. & • & \\
\hline Punctatisporites minutus Kosanke, 1950 & & o \\
\hline Punctatisporites punctatus Ibrahim, 1932 (in Potonié, Ibrahim et Loose, 1932) & & o \\
\hline Calamospora mutabilis (Loose) Schopf, Wilson et Bentall, 1944 & & • \\
\hline Calamospora sp. & o & o \\
\hline Granulatisporites minutus Potonié et Kremp, 1955 & & o \\
\hline Granulatisporites granulatus Ibrahim, 1933 & & o \\
\hline Verrucosisporites sp. & o & o \\
\hline Cyclogranisporites sp. & & o \\
\hline Lophotriletes pseudaculeatus Potonié et Kremp, 1955 & & 0 \\
\hline Lophotriletes sp. & o & o \\
\hline Anapiculatisporites minor (Butterworth et Williams) Smith et Butterworth, 1967 & o & • \\
\hline Apiculatisporites cf. setulosus (Kosnake) Potonié et Kremp, 1955 & & o \\
\hline Apiculatisporites sp. & o & o \\
\hline Apiculatasporites spinulistratus (Loose) Ibrahim, 1933 & & o \\
\hline Acanthotriletes cf. echinatus (Knox) Potonié et Kremp, 1955 & o & \\
\hline Acanthotriletes sp. & o & \\
\hline Raistrickia cf. superba (Ibrahim) Schopf, Wilson et Bentall, 1944 & & o \\
\hline Raistrickia major Bhardwaj, 1957 & & 0 \\
\hline Raistrickia sp. & & o \\
\hline Convolutispora sp. & & o \\
\hline Microreticulatisporites cf. fistulosus (Ibrahim) Knox, 1950 & & o \\
\hline Dictyotriletes densoreticulatus Potonié et Kremp, 1955 & & • \\
\hline Dictyotriletes cf. falsus Potonié et Kremp, 1955 & & o \\
\hline Dictyotriletes reticulocingulum (Loose) Smith et Butterworth, 1967 & & o \\
\hline Dictyotriletes bireticulatus (Ibrahim) Smith et Butterworth, 1967 & o & \\
\hline Reticulatisporites alveolatus Knox, 1950 & & o \\
\hline Triquitrites sculptilis (Balme) Smith et Butterworth, 1967 & o & \\
\hline Triquitrites cf. tricuspis (Horst) Potonié et Kremp, 1956 & o & \\
\hline Triquitrites sp. & $\bullet$ & \\
\hline
\end{tabular}




\begin{tabular}{|c|c|c|}
\hline \multirow{2}{*}{ TAXA } & \multicolumn{2}{|c|}{ Locality } \\
\hline & Br 1 & Gl \\
\hline Tripartites vetustus Schemel, 1950 & o & \\
\hline Mooreisporites inusitatus (Kosanke) Neves, 1961 & o & 0 \\
\hline Reinschospora triangularis (Kosanke) Ravn, 1979 & & o \\
\hline Savitrisporites concavus Marshall and Smith, 1965 & & • \\
\hline Savitrisporites nux (Butterworth et Williams) Smith et Butterworth, 1967 & & $\bullet$ \\
\hline Savitrisporites sp. & • & o \\
\hline Crassispora kosankei (Potonié et Kremp) Bharadwaj, 1957 & & o \\
\hline Crassispora $\mathrm{sp}$. & o & o \\
\hline Gorgonispora convoluta (Butterworth et Spinner) Playford, 1976 & & - \\
\hline Densosporites sp. & o & \\
\hline cf. Lycospora sp. & o & \\
\hline Lundbladispora cf. gigantea Alpern, 1959 & & - \\
\hline Alatisporites pustulatus (Ibrahim) Irahim, 1933 & & 0 \\
\hline Cirratriradites cf. saturni (Ibrahim) Schopf, Wilson et Bentall, 1944 & & o \\
\hline Cirratriradites sp. & o & o \\
\hline Microspinosporites orbiculus (Potonié et Kremp) Bek, 2013 & & o \\
\hline Spencerisporites cf. radiatus (Ibrahim) Drábková, Bek et Opluštil, 2004 & o & \\
\hline Endosporites zonalis (Loose) Knox, 1950 & $\bullet$ & o \\
\hline Endosporites globiformis (Ibrahim) Schopf, Wilson et Bentall, 1944 & o & \\
\hline Endosporites cf. zonalis sp. & o & \\
\hline Laevigatosporites desmoinesensis (Wilson et Coe) Schopf, Wilson et Bentall, 1944 & o & $\bullet \bullet$ \\
\hline Laevigatosporites medius Kosanke, 1950 & & $\bullet$ \\
\hline Laevigatosporites minimus (Wilson et Coe) Schopf, Wilson \& Bentall, 1944 & & - \\
\hline Latosporites latus (Kosanke) Potonié et Kremp, 1956 & & $\bullet$ \\
\hline Vestispora magna (Butterworth et Williams) Smith et Butterworth, 1967 & & o \\
\hline Vestispora sp. & o & $\bullet$ \\
\hline Florinites mediapudens (Loose) Potonié et Kremp, 1956 & & o \\
\hline Florinites visendus (Ibrahim) Schopf, Wilson et Bentall, 1944 & o & \\
\hline Florinites sp. & $\bullet$ & \\
\hline Wilsonites sp. & $\bullet$ & \\
\hline Guthörlisporites volans (Loose) Loboziak & 0 & \\
\hline Guthörlisporites sp. & $\bullet$ & \\
\hline Potonieisporites sp. & $\bullet$ & \\
\hline Pityosporites westphalensis Wiliams, 1955 & o & \\
\hline
\end{tabular}

Occurrence: $\cdots$ Abundant, ••Common, • Frequent, o Rare

\section{Plate I.}

1. Landscape near Brandov with heap near Br 3 locality (arrows). Heidersdorf village on the background.

2 . View to the coal (anthracite) seam with a small fault (dashed line) ( $\mathrm{Br} 1)$.

3.-4. Outcrop $\mathrm{Br} 1$, where fossil flora has been collected.

5. Detail of the layer from Fig. 4 with many cordaitalean remains (Br 1). 
Plate I.

1
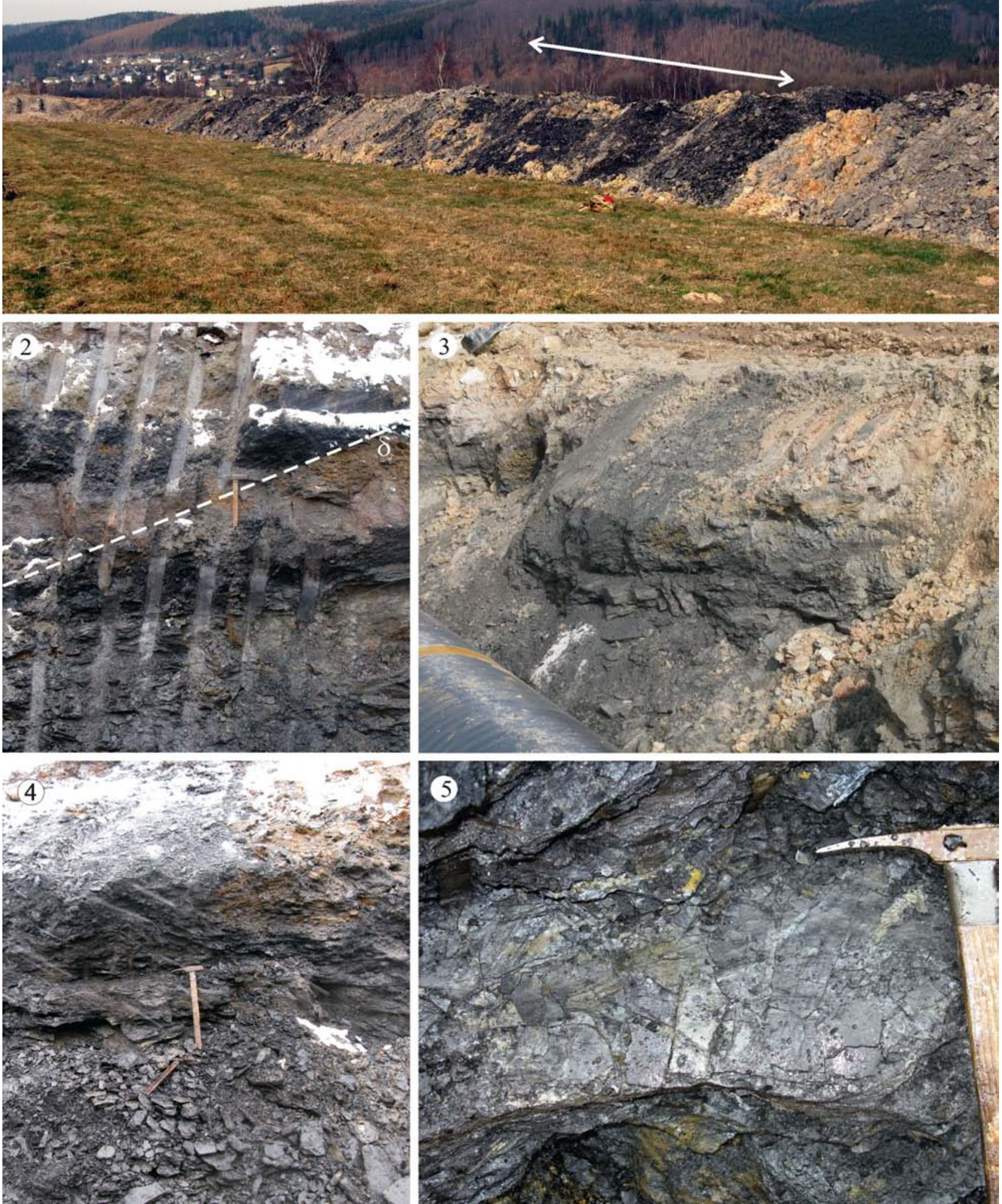
Plate II.

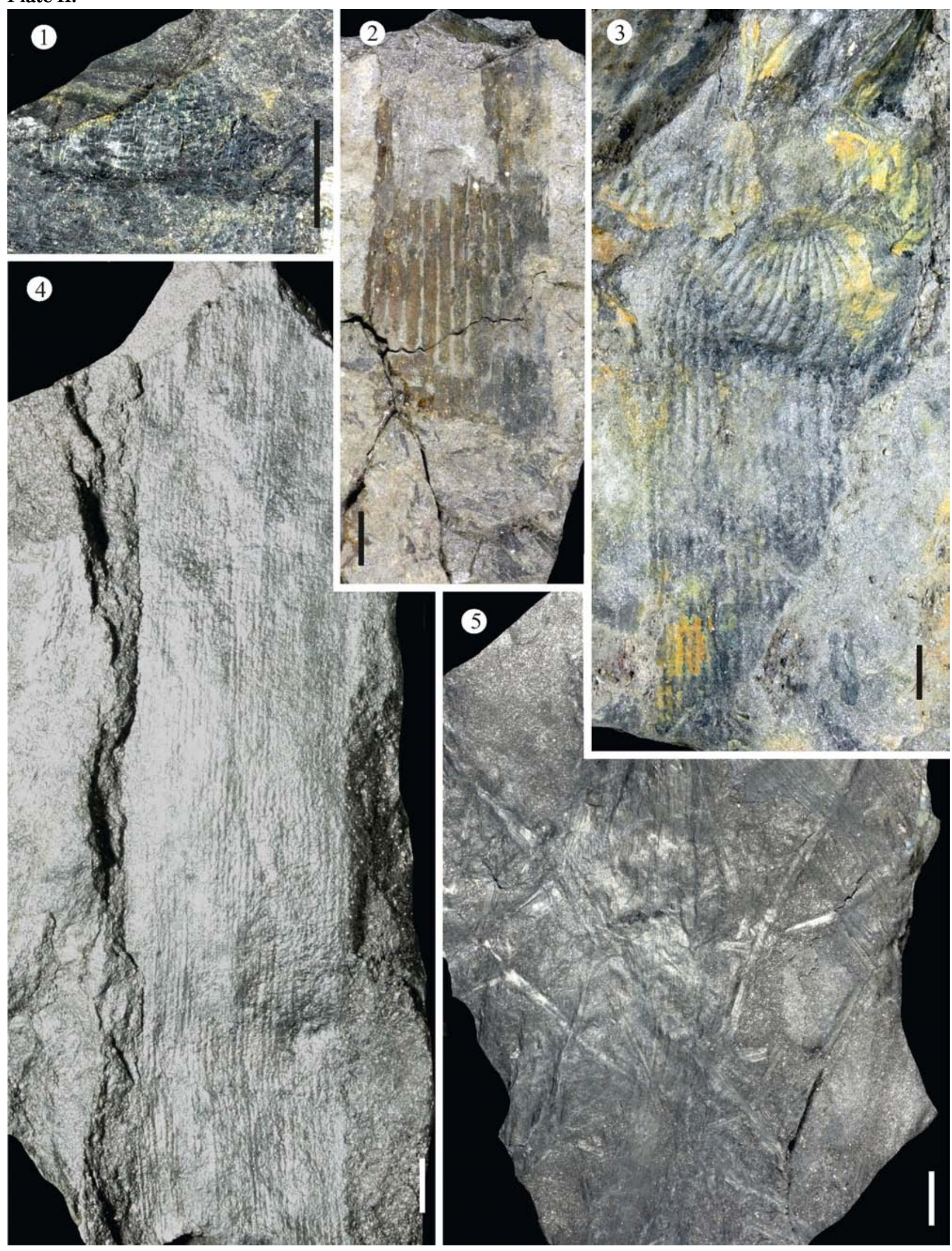


Plate III.

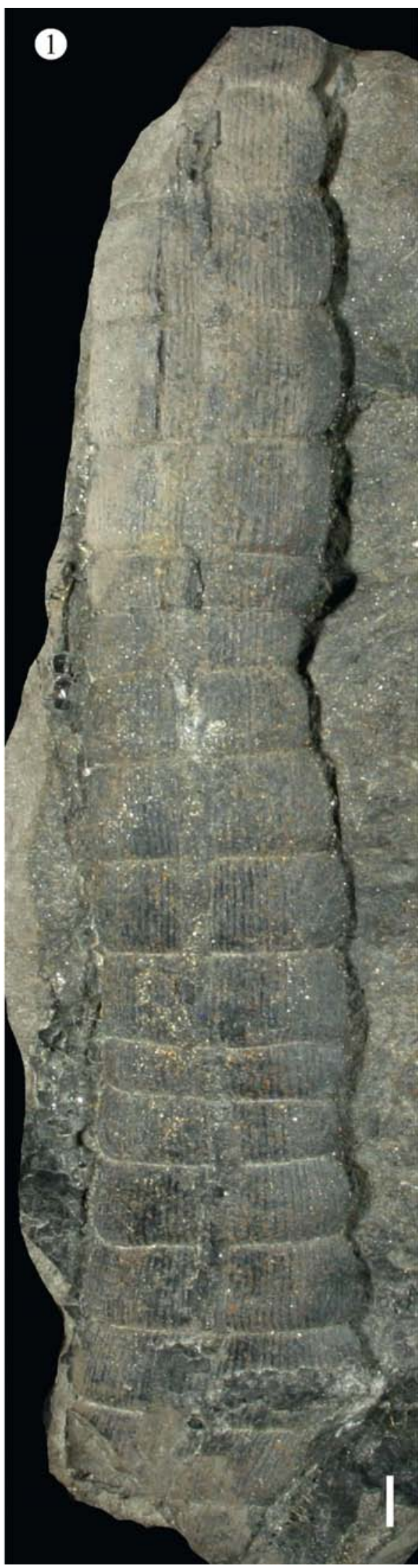

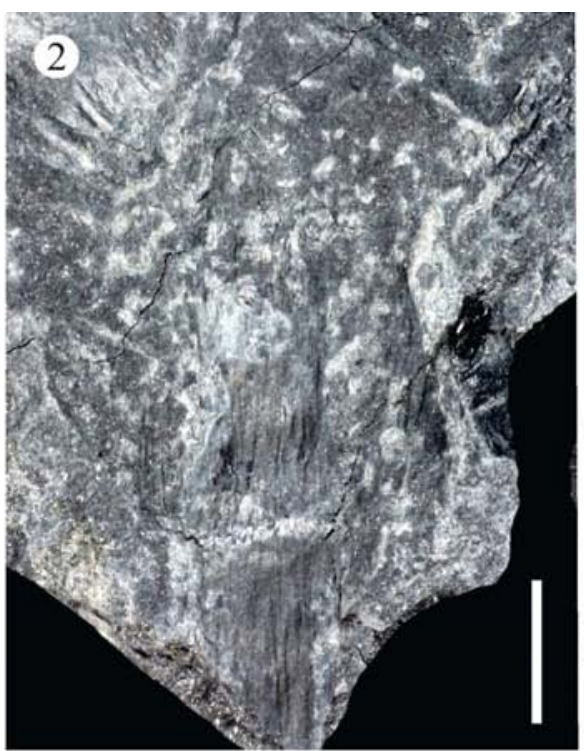
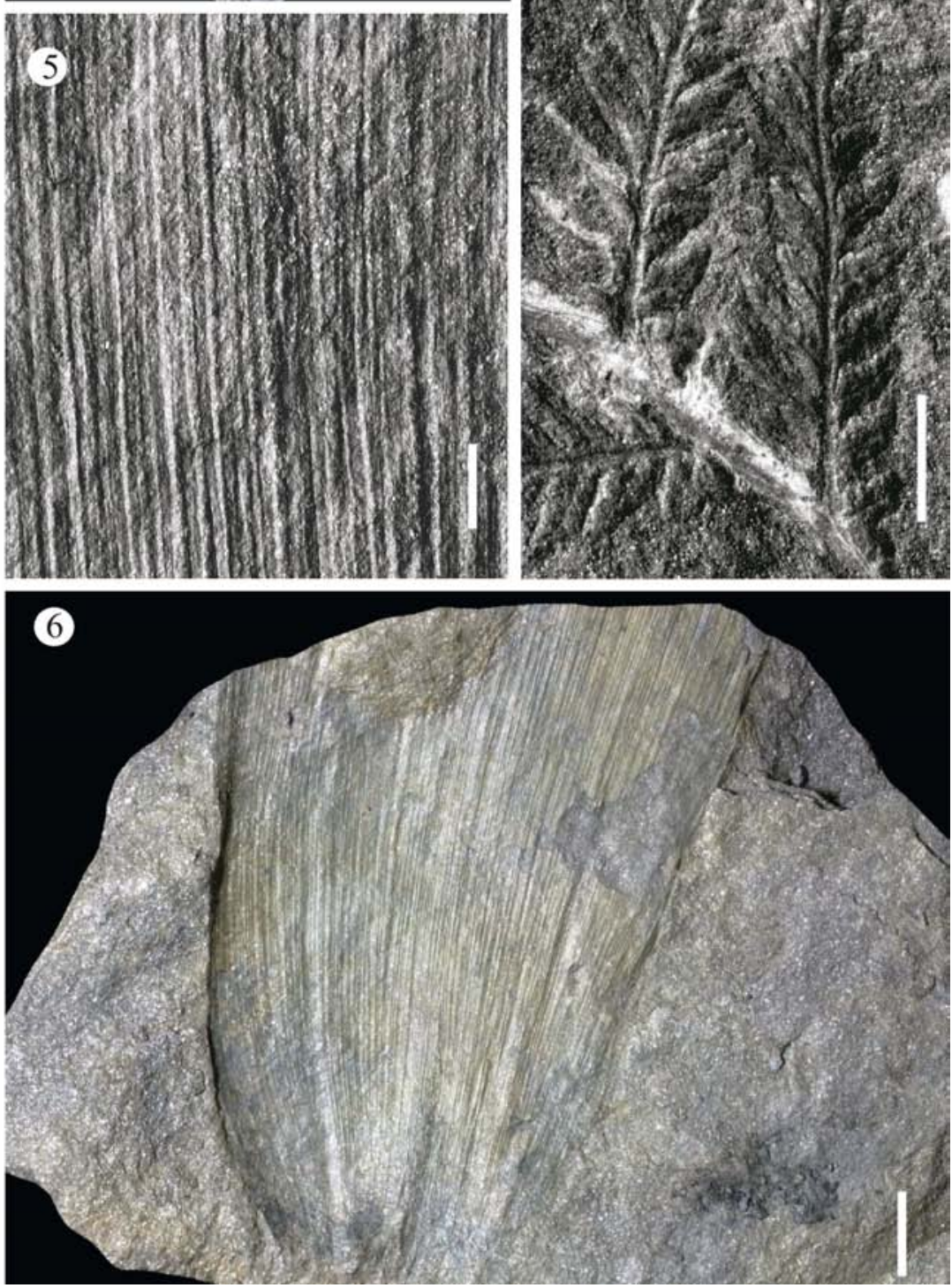


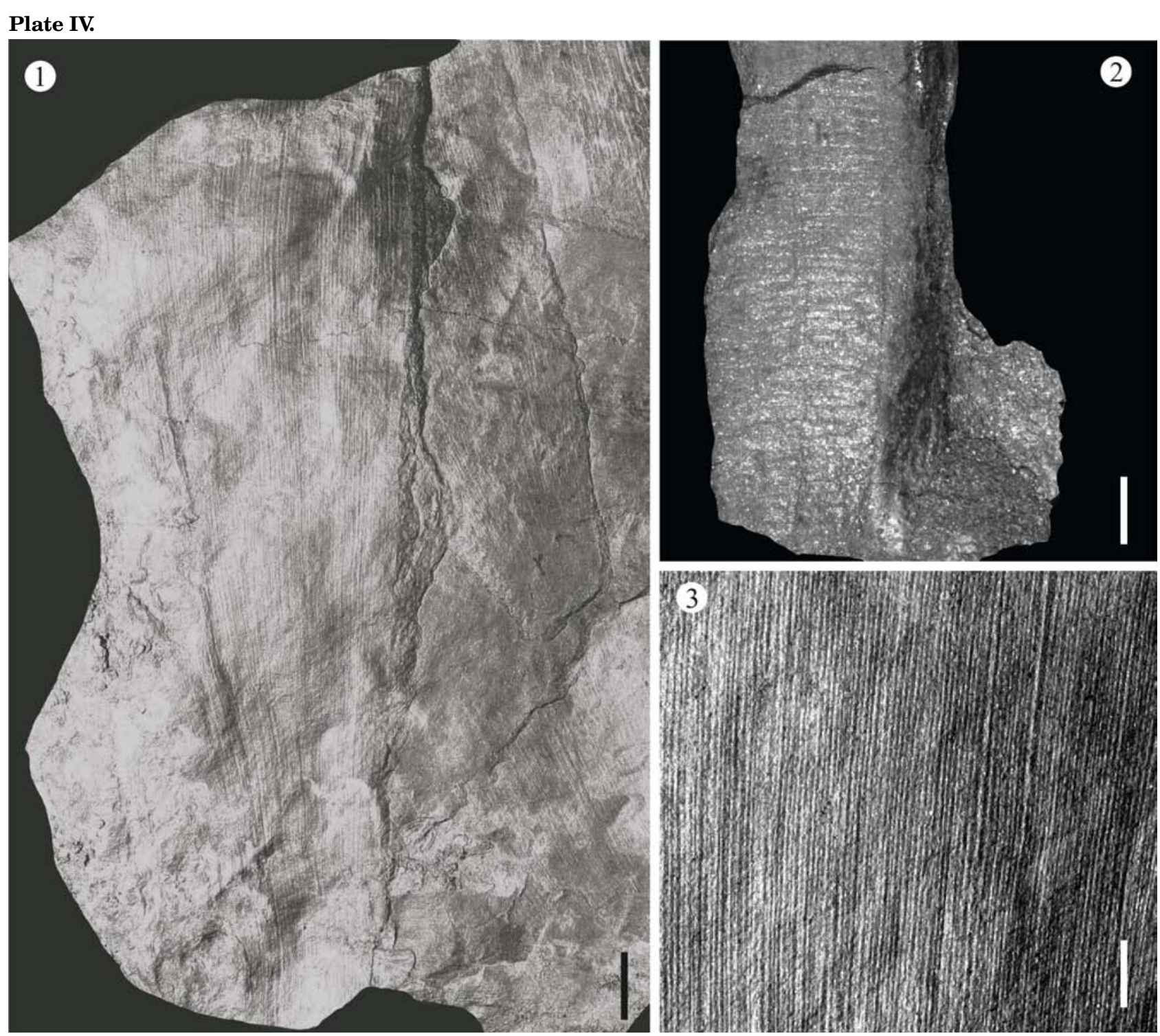

Plate IV.

1. Cordaites sp., Br 3. Coll. ZŠ 557, Scale bar $=1 \mathrm{~cm}$.

2. Artisia cf. approximata, Br 1. Coll. ZŠ 558 , Scale bar $=1 \mathrm{~cm}$.

3. Detail of venation of Cordaites sp. Venation type Cordaites palmaeformis. Br 3 . Scale bar $=2 \mathrm{~mm}$.

Plate II. (page 13)

1. Lepidostrobus sp., loc. Br 1 . Coll. ZŠ 551, scale bar $=1 \mathrm{~cm}$.

2. Calamites suckowii, loc. $\mathrm{Br} 1$. Coll. ZŠ 552 , scale bar $=1 \mathrm{~cm}$.

3. Calamites carinatus, loc. Br 1. Coll. ZŠ 392 , scale bar $=1 \mathrm{~cm}$.

4. Calamites cistii, loc. Br 3. Coll. ZS 393, scale bar $=1 \mathrm{~cm}$.

5. Cyperites sp. loc. Br 3. Coll. ZŠ 553, scale bar $=1 \mathrm{~cm}$.

Plate III. (page 13)

1. Calamites schuetzeiformis, loc. Brandov, dump of the "Glück auf" coal mine. Coll. ZŠ 394, scale bar $=1 \mathrm{~cm}$.

2. Asterophyllites cf. longifolius, Br 1. Coll. ZŠ 554, Scale bar $=1 \mathrm{~cm}$.

3. Senftenbergia plumosa. Br 3. Coll. ZŠ 555, Scale bar $=1 \mathrm{~cm}$.

4. Detail of 2 ultimate pinnae of Senftenbergia plumosa. Br 3. Scale bar $=5 \mathrm{~mm}$.

5 . Detail of venation of Cordaites sp. Venation type Cordaites principalis. Br 2. Scale bar $=2 \mathrm{~mm}$.

6. Cordaites sp., Br 2. Coll. ZŠ 556, scale bar $=1 \mathrm{~cm}$. 


\section{Plate V.}
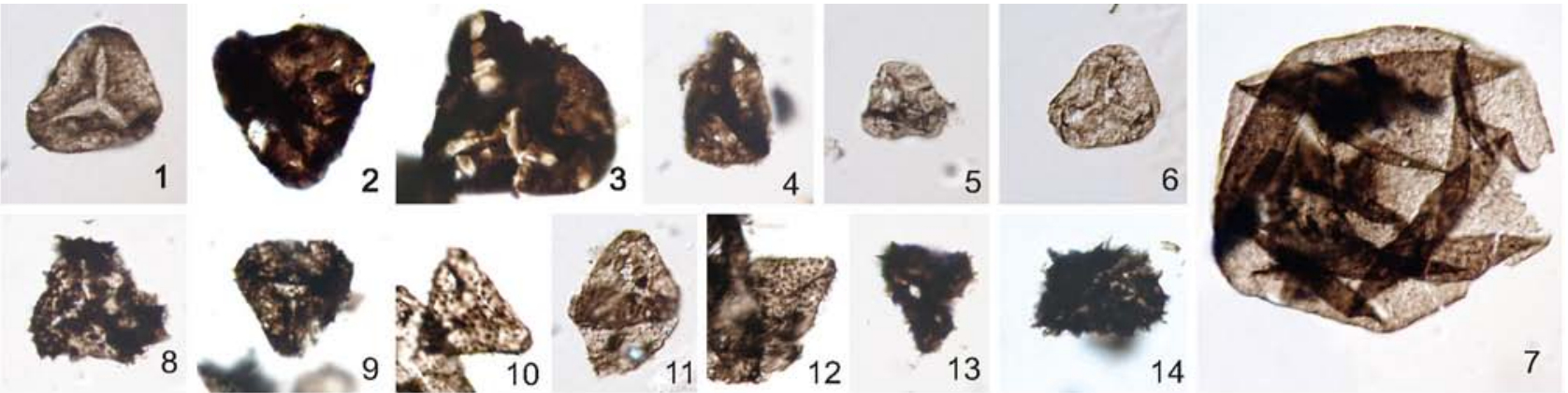



15

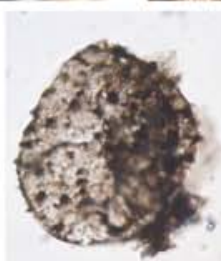

16

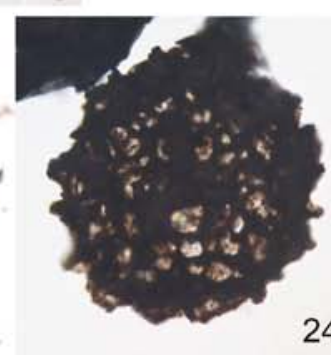

17
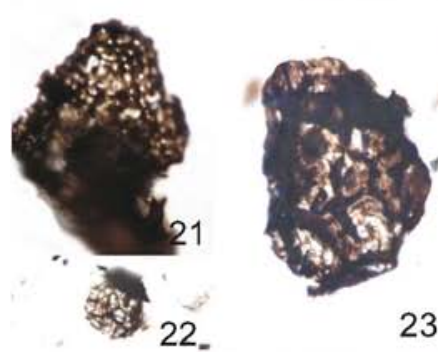

23


18



19

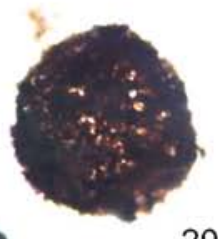

20

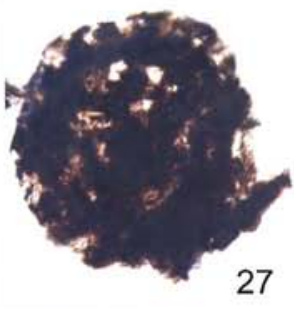


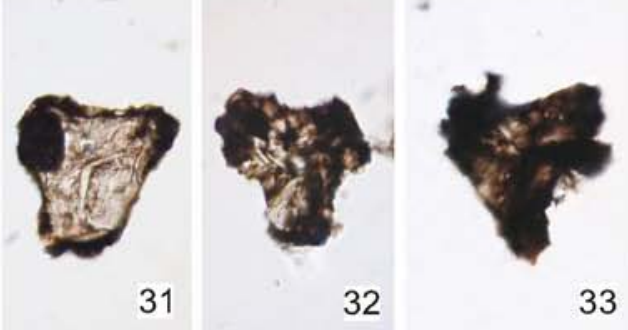

32


36

37


L
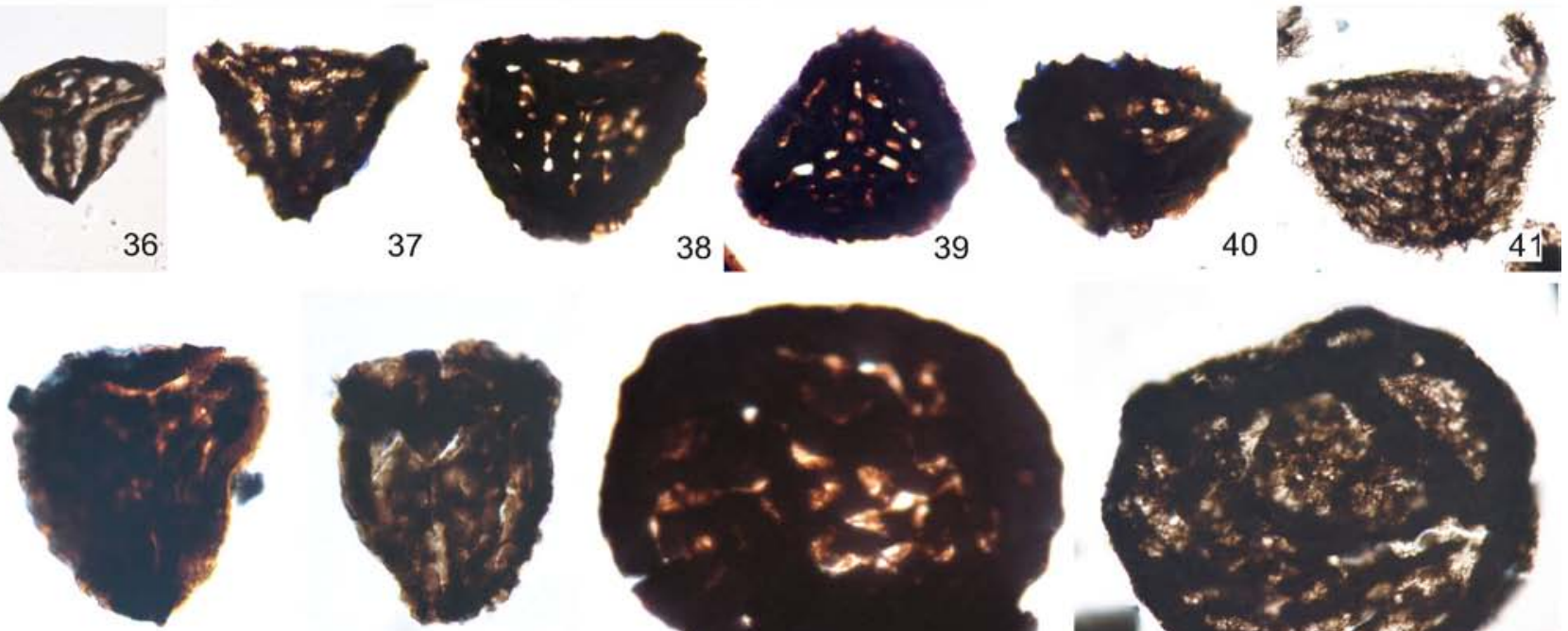

42

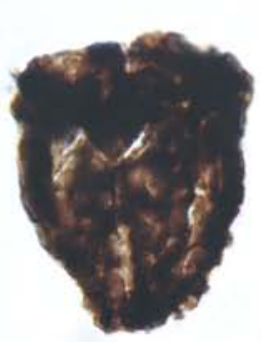

43



\section{Plate VI.}
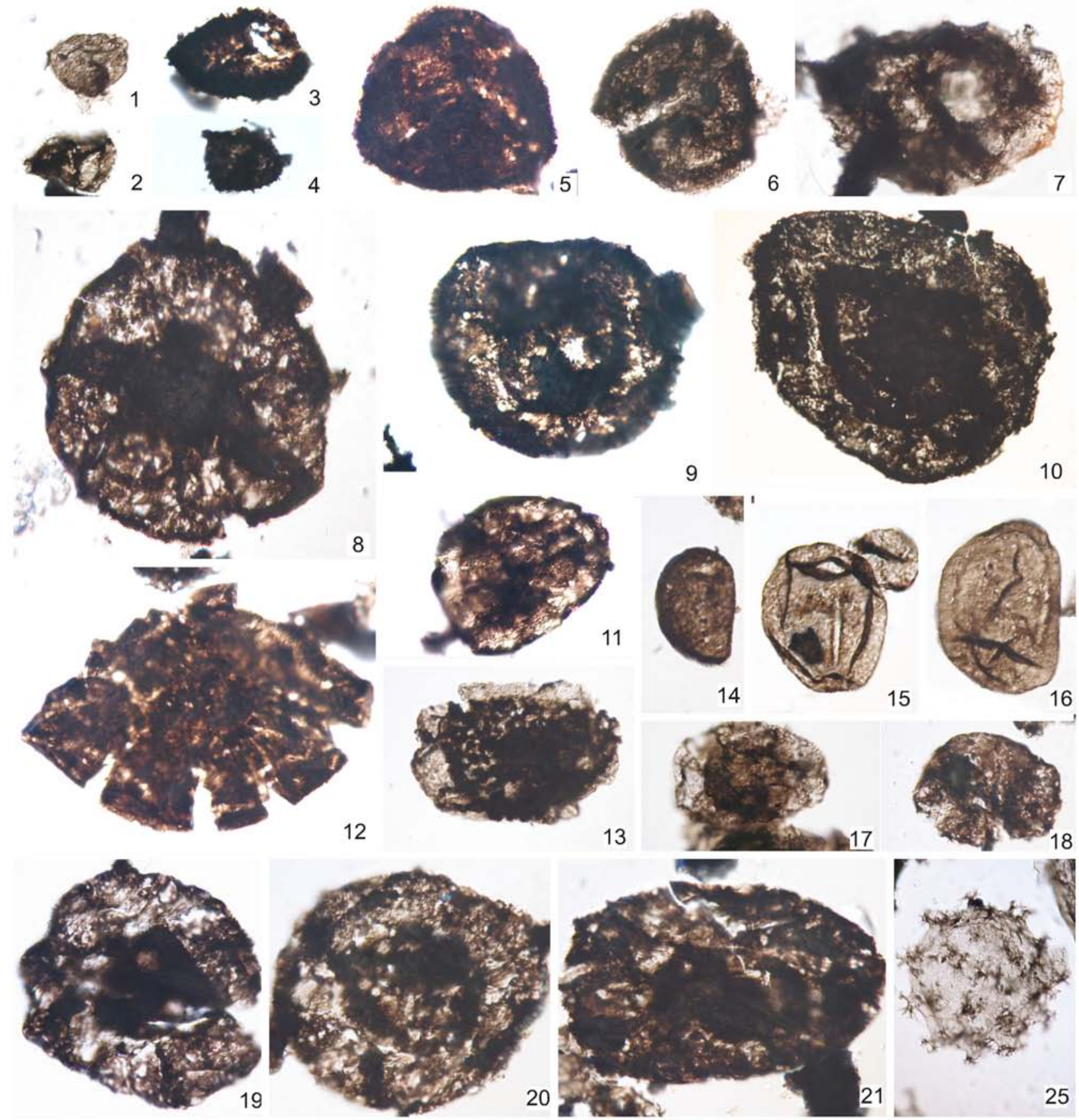

$13 \quad 12$ 세 17
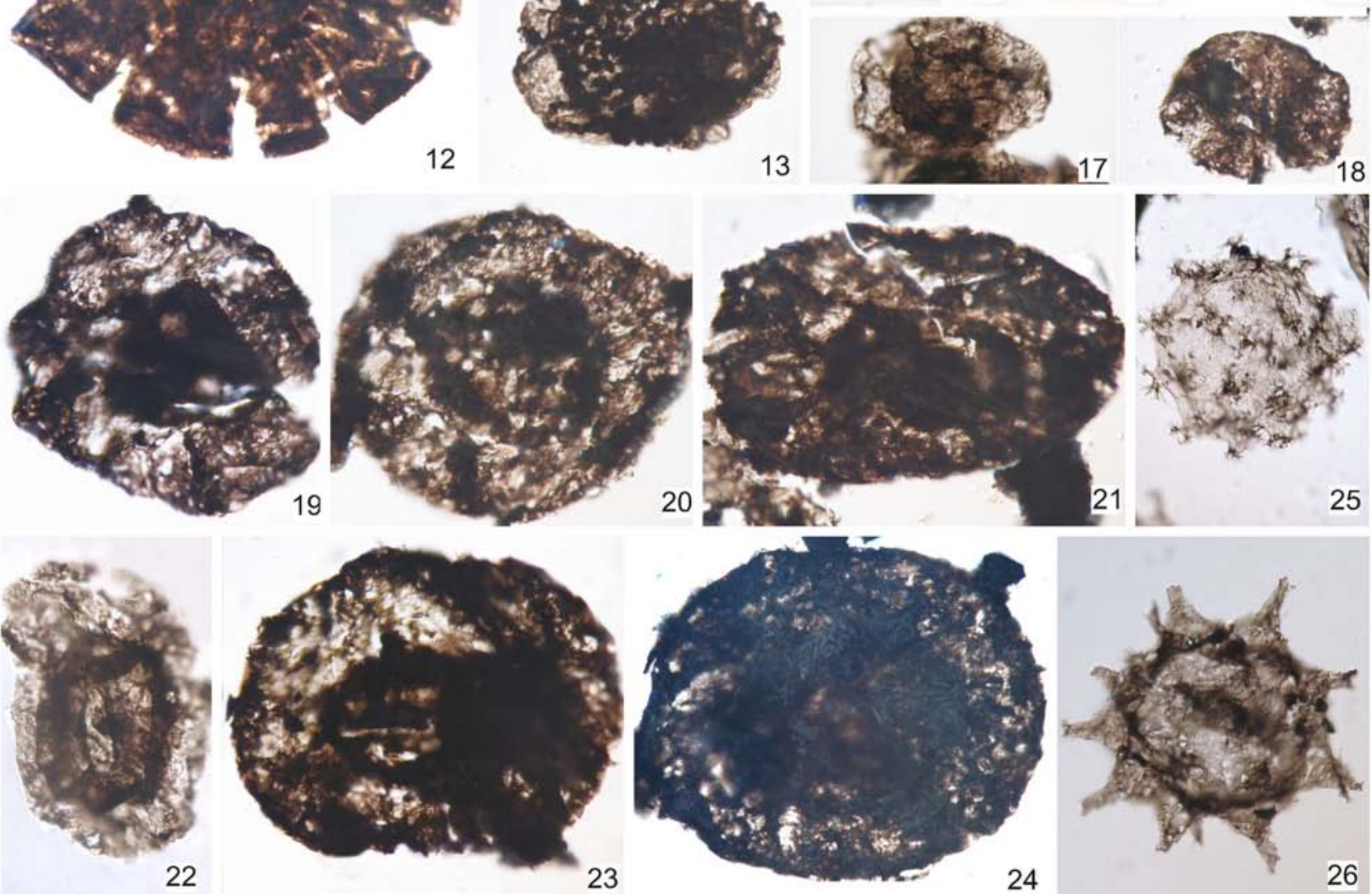

21

25






\section{Zbyněk Šimůnek, Bedřich Mlčoch and Jana Drábková, New geological, palaeobotanical and palynological evidence}

Plate V. (page 15)

All figures of miospores are $\times 500$ enlagered, unless stated else. Brandov 1 locality (loc. Br 1), dump of the "Glück auf" mine (loc. Gl),

1. Leiotriletes adnatoides, loc. Brandov 1 ( $\mathrm{Br} 1)$.

2. Leiotriletes cf. convexus, loc. Gl.

3. Leiotriletes sphaerotriangulus, loc. Gl.

4. Leiotriletes tumidus, loc. $\mathrm{Br} 1$.

5. Granulatisporites minutus, loc. Gl.

6. Granulatisporites granulatus, loc. Gl.

7. Calamospora mutabilis, loc. Gl.

8. Lophotriletes sp., loc. $\mathrm{Br} 1$.

9. Lophotriletes sp., loc. $\mathrm{Br} 1$.

10.-12. Anapiculatisporites minor, loc. Gl.

13. Acanthotriletes sp., loc. $\mathrm{Br} 1$.

14. Acanthotriletes cf. echinatus, loc. $\mathrm{Br} 1$.

15. Lophotriletes pseudaculeatus, loc. Gl.

16. Apiculatisporites cf. setulosus, loc. Gl.

17. Apiculatisporites sp., loc. $\mathrm{Br} 1$.

18. Apiculatisporites spinulistratus, loc. Gl.

19. Raistrickia cf. superba, loc. Gl.

20. Convolutispora sp., loc. Gl.

21. Microreticulatisporites cf. fistulosus, loc. Gl.

22. Reticulatisporites alveolatus, loc. Gl.

23. Dictyotriletes bireticulatus, loc. $\mathrm{Br} 1$.

24.-25. Dictyotriletes densoreticulatus, loc. Gl.

26. Dictyotriletes reticulocingulum, loc. Gl.

27. Dictyotriletes sp., loc. Gl.

28. Triquitrites sculptilis, loc. $\mathrm{Br} 1$.

29. Triquitrites sp., loc. $\mathrm{Br} 1$.

30. Triquitrites $\mathrm{cf}$. sculptilis, loc. $\mathrm{Br} 1$.

31. Triguitrites cf. tricuspis, loc. $\mathrm{Br} 1$.

32. Tripartites vetustus, loc. $\mathrm{Br} 1$.

33. Mooreisporites inusitatus, loc. $\mathrm{Br} 1$.

34. Mooreisporites inusitatus, loc. Gl.

35. Reinschospora triangulata, loc. Gl.

36. Savitrisporites concavus, loc. Gl.

37. Savitrisporites sp., loc. Gl.

38. Savitrisporites nux, loc. Gl.

39. Savitrisporites nux, loc. Gl.

40. Savitrisporites sp., loc. Gl.

41. Savitrisporites sp., loc. Gl.

42.-43. Savitrisporites sp., loc. Br 1.

44. Gorgonispora convoluta, loc. Gl, ?400

45. Gorgonispora convoluta, loc. Gl, ?400.

Plate VI. (page 16)

All figures of miospores and acritarchs are $\times 500$ enlagered, unless stated else.

Locality Brandov 1 (loc. Br 1), dump of the "Glück auf" mine (loc. Gl),

1. Microspinosporites orbiculus, loc. Gl.

2. Lycospora? sp., loc. Br 1.

3.-4. Densosporites sp., loc. $\mathrm{Br} 1$.

5. Lundbladispora sp., loc. Gl.

6. Crassispora sp., loc. Gl.

7. Cirratriradites cf. saturni, loc. Gl.

8. Endosporites globiformis, loc. $\mathrm{Br} 1$.

9. Endosporites zonalis, loc. Br 1.

10. Spencerisporites cf. radiatus, loc. $\mathrm{Br} 1 . ? 200$.

11. Endosporites sp., loc. $\mathrm{Br} 1$.

12. Vestispora magna, loc. Gl.

13. Alatisporites pustulatus, loc. Gl.

14. Laevigatosporites medius, loc. Gl.

15. Laevigatosporites desmoinesensis and L. minimus, loc. Gl.

16. Laevigatosporites desmoinesensis, loc. Gl.

17. Florinites mediapudens, loc. Gl.

18. Pityosporites westphalensis, loc. $\mathrm{Br} 1$.

19. Wilsonites sp., loc. $\mathrm{Br} 1$.

20. Wilsonites sp., loc. $\mathrm{Br} 1$.

21. Guthörlisporites volans, loc. $\mathrm{Br} 1$.

22. Potonieisporites sp., loc. $\mathrm{Br} 1$.

23. Potonieisporites sp. loc. $\mathrm{Br} 1$.

24. Monosaccate pollen grain, $\times 400$

25.-26. Acritarcha, loc. Gl. 


\section{PALYNOLOGY}

The palynomorphs from the Brandov Basin are here reported on for the first time, 36 genera and 51 species of miospores are present. Miospore assemblage is poorly preserved. Spores are strongly degraded due to transport and are usually dark brown to brown-black due to coalification. Identified miospore taxa are given in the Table 2, and some are figured in Plates V and VI.

Brandov ( $\mathrm{Br} 1$ ) has the following pollen and spore assemblage. Monosaccate pollen Florinites and Guthörlisporites are abundant. Potonieisporites and bisaccate pollen grains Pityosporites westphalensis are present. However, most monosaccate pollen grains are indeterminate due to poor preservation. Spores are represented by, most to least common, Leiotriletes, Savitrisporites and Endosporites. Other more spars taxa are Triquitrites, Laevigatosporites, Lycospora and Spencerisporites among others. In some samples, pollen of cordaitaleans, pteridosperms and possibly conifers, dominate over fern spores. Spores produced by subarborescent lycopsids of the genera Polysporia and Spencerites are very rare.

The laevigate monolete spores Laevigatosporites (L. desmoinesensis, L. medius Kosanke, 1950) and Latosporites (L. latus) is dominate the dark grey mudstones ("Glück auf" mine). The common taxa in order of decreasing dominance in the sample are, spores of Savitrisporites (S. nux, S. concavus and Savitrisporites sp.) and Dictyotriletes densoreticulatus, Anapiculatisporites minor, Vestispora magna, Calamospora, Apiculatisporites and Crassispora. Those less common are Gorgonispora, Lundbladispora, Cirratriradites and Microspinosporites, Florinites.

The spore assemblage of the "Glück auf" mine is characterized by the dominance of spores of sphenophylls and subdominance of spores produced by ferns, calamitaleans, selaginellas and sigillarians. Spores other plant groups (e.g. Flemingites, Cordaites) are rare.

\section{STRATIGRAPHY}

Němejc (1930) updated the floral lists found in Jokély (1857), Geinitz (1856) and Feistmantel, O. (1873), which were based on the collections housed in the museum in Chemnitz and the National Museum in Prague. Němejc (1930) ascertained that most of the plant fossils came from the roof of the coal seam no. III in the Brandov coal measure. Šimůnek in Pešek et al. (2001) for the most part adopted Němejc's (1930) floral list.

Němejc (1930) regarded sigillarian, ferns and pteridosperms as stratigraphically important plants and compared the Brandov flora with the Central Bohemian flora and floras from the small basins in Saxony. Based on the presence of Saccopteris angustissima (later synonym Alloiopteris angustissima) (Sternberg) Potonié, Sphenopteris stipulata Gutbier et Geinitz, Eusphenopteris nummularia (Brongniart) Novik, Pecopteris (Senftenbergia) pennaeformis Brongniart and Pecopteris miltonii Artis, Němejc thought that the peat-forming sequence of the Brandov C.R. was Moscovian (Upper Westphalian) and compared it with the Radnice Member. This correlation was strongly influenced by the co-occurrence of Saccopteris angustissima and Sphenopteris stipulata in both regions. Němejc (1953) later re-evaluated this correlation strongly relying on the presence of Sigillaria schlotheimiana (Namurian B to Westphalian A) in the Brandov flora correlated it with the Langsettian (upper Westphalian A). Havlena (1964) preferred Němejc's (1930) original determination of the age of the Brandov C.R. - Duckmantian or Bolsovian (Westphalian B or C).

Most of the species from the Brandov C.R. show a stratigraphic range from Bashkirian (upper Namurian) to Moscovian (lower Bolsovian). For more reliable stratigraphy, Sphenophyllum myriophyllum Crépin (upper Duckmantian - lower Bolsovian) and Annularia spinulosa Sternberg (formerly A. stellata Schlotheim) (middle Bolsovian - Permian) could be important. Unfortunately the Němejc's (1930) specimens relied on for his determinations and correlations have not been adequately preserved. Němejc's (1930) published a list of 38 taxa from the Brandov C.R. Simůnek in Pešek et al. (2001) mention only 30 species (not including taxa identified with "sp." or other decorticated forms).

The fern Senftenbergia plumosa (Artis) Stur was found in the outcrop $\mathrm{Br} 3$ and thus confirmed the presence of this species in the Brandov C.R. Artisia cf. approximata Lindley et Hutton from locality $\mathrm{Br} 1$ is a newly identified taxon for this region. Another new species for the Brandov C.R. comes from the "Glück auf" mine dump in Brandov village 
and was found by B. Mlčoch. It probably represents a pith cast of the sphenopsid Calamites $\mathrm{cf}$. schuetzeiformis Kidston. Němejc (1930, pl. 4, fig. 10) figured a specimen, but was not secure in a more precise identification than Calamites sp.

The species Dictyotriletes bireticulatus, D. densoreticulatus, D. reticulocingulum, Anapiculatisporites minor, Reinschospora, Mooreisporites inusitatus, Alatisporites pustulatus, Cirratriradites saturni, Endosporites zonalis, Savitrisporites nux, Savitrisporites concavus, and Vestispora magna are stratigraphically significant taxa. These taxa can precisely correlated with assemblages of the Prkenný Důl-Žd'árky Member from the Intrasudetic Basin and the Radnice coal seams of the Central Bohemian Upper Palaeozoic . However, some taxa typically present in these units have not been identified in the Brandov Basin. most notably Lycospora sp., Punctatisporites obesus, Reticulatisporites muricatus and Knoxisporites polygonalis. Nevertheless, a latest Duckmantian or early Bolsovian for the Brandov C.R. is well supported.

\section{PALAEOECOLOGICAL EVALUATION}

The most common plant remains in the study localities are cortaitalean leaves and calamitalean pith casts. Their position in the section could be studied only at locality Brandov 1 ( $\mathrm{Br} 1)$, where trench walls were accessible for collecting. Sphenopsids - calamitaleans grew predominantly on river banks (Behrensmeyer et al., 1992), but they apparently were tolerant to dynamic environmental conditions, they also grew in sandy deposits. It is not unusual in other location to find upright but in Brandov only short fallen stem fragments that suggest some transport were recovered. Sporadically, a cordaitalean stem with Artisia-type pith cast was found among calamitalean remains. In the lower part of the sandstone layer, indeterminate stems with smooth surfaces dominated first fossiliferous layer.

The second fossiliferous layer (above the sandstone) is represented by grey and black claystones (Plate 1, Fig. 5). Only cordaitalean leaf accumulations were found here. The "assemblage" beneath the coal seam is difficult to evaluate, because different cordaitalean species grew on different substrates from dry, well drained, to wet, partly inundated (Behrensmeyer et al., 1992). We do not know the ecological demands of these plants, but they must have been transported a short distance (parautochthonous) because they are well preserved. Their fragmentary nature of the specimens is due to the friable claystone, they were more complete in the sediment but could not be recovered. Most probably these plants represent wet conditions, because they are preserved in fine clastic deposits immediately below the coal seam. Here conditions started to change from seasonal to ever wet, but cuticles are not preserved to prove our hypothesis.

The differences among palynological assemblages of the localities evidently reveal palaeoecologic and taphonomic biases. In contrast to miospore assemblages of the Radnice and Prkenný DůlŽd'árky members, the Brandov assemblages are impoverish for many taxa. The most important difference is the absence of the spore Lycospora in the Brandov C.R.

\section{DISCUSSION}

The slight metamorphism is manifested only on coal and claystones. The coal is coalified to anthracite stage. It is evident that coal is not appropriate for cuticular and palynological studies according to the following characteristics: $R_{r}=$ $3.8-4.3 \%$ and $\mathrm{V}^{\mathrm{daf}}=3.8 \%$ (Sýkorová in Pešek et $a l ., 2001)$. The palynomorphs were obtained from claystones and mudstones exhibiting little if any metamorphism. The poor preservation of palynomorphs is due to combination of high coalification, which caused changes during the fossilisation process; and primarily, because palynomorphs are transported to the site of deposits from different habitats, often after long water transport. They are corroded and differently destroyed before sedimentation and fossilization. It is not surprising that the obtained spore assemblages are poor in comparison with assemblages from Radnice and Prkenný Důl-Žd'árky members (Kladno-Rakovník and Intrasudetic basins). The important thing is that palynomorhs from the Brandov localities were obtained only from mudstones and claystones, whereas those from Kladno-Rakovník and Intrasudetic basins they are predominantly from coal.

The fossilized leaf fragments of cordaitaleans found on claystones are bright and cuticles are not preserved. The upper unit is a red bed and similarly to the rhyolitic tuff are unfossiliferous. 


\section{CONCLUSION}

The crystalline basement belongs to Sayda Dome and not to Hora Svaté Kateřiny (Katharinaberg) Dome as formerly interpreted. An older Carboniferous unit [Moscovian, (Bolsovian)] is present in the "Northern depth" of the basin, including an anthracite coal seam previously unknown. The areal extent of the younger Carboniferous unit (Stephanian - Kasimovian or Gzhelian) is significantly less than previously mapped (see Figure 1). The Quaternary is represented by colluvial and fluvial deposits, and the Holocene grey clayey layer is palynologically dated as $500-100$ years old.

During the construction of gas-pipeline "Gazela" near Brandov a heretofore unknown flora was discovered in the "Northern depth". However, it is not divers nor well preserved. It differs from the "ordinary" assemblage collected during the mining activity in the "Southern depth" of the Brandov C.R. (Nermejc, 1930). The assemblages from the "Northern depth" contain many cordaitalean and calamitalean remains, whereas assemblages studied by Nemejc (1930) are typically dominated by lycopsids, namely Sigillaria that are considered peatforming plants. This difference could maybe explained by the fact that the newly studied assemblage is from the edge of the basin as well as from strata below the coal seam, whereas the assemblage studied by Němejc (1930) comes from the centre of the basin and therefore different palaeoecologic and sedimentologic conditions.

The species formerly unknown from the Brandov C.R. include: Artisia cf. approximata Lindley et Hutton, and Calamites schuetzeiformis Kidston. Senftenbergia plumosa was newly discovered during the gas-pipeline construction.

Palynomorphs are identified from the Brandov Basin for the first time. Pollen grains of cordaitaleans, pteridosperms and possibly conifers prevail over fern spores in the pipeline excavation, whereas, sphenophyll spores dominate in the samples from the "Glück auf" mine dump; spores produced by ferns, calamitaleans and sigillarians are subordinate.

\section{ACKNOWLEDMENTS}

The authors thank for the support of the Grant Agency of the Czech Republic (Grant project P210/ 12/2053).

\section{REFERENCES}

Artis, E. T. 1825. Antediluvian phytology. Nichols and Son, 24 p. London.

Batten, D. J. 1999. Small palynomorphs, 16-19; in: Jones T. P., Rowe N. P. (eds) Fossil plants and spores: modern techniques. The Geological Society London, $396 \mathrm{pp}$.

Behrensmeyer, A. K., Damuth, J, D., DiMichele, W. A., Potts, R., Sues, H.-D. a Wing, S. L. 1992. Terrestrial ecosystems through time. Evolutionary palaeonology of terrestrial plants and animals. The University Chicago Press, 568 pp., Chicago and London.

Bek, J., Drábková, J., Dašková, J., Libertín, M. 2008. The sub-arborescent lycopsid genus Polysporia Newberry and its spores from the Pennsylvanian (Bolsovian-Stephanian B) continental basins of the Czech Republic. Review of Palaeobotany and Palynology, 152, 176-199.

Bek, J., Opluštil, S. 1998. Some lycopsid, sphenopsid and pteropsid fructifications and their miospores from the Upper Carboniferous basins of the Bohemian Massif. Palaeontogr., Abt. B 248, 127-161.

Bek, J., Pšenička, J. 2003. Cuticles and spores of Senftenbergia plumosa (Artis) Bek and Pšenička from the Carboniferous of Pilsen Basin, Bohemian Massif. Review of Palaeobotany and Palynology, 125, 299-312.

Brongniart, A. T. 1828a-1838. Historie des végétaux fossiles, ou recherches botaniques et geologiques sur les végétaux renfermés dans les diverses couches du globe. Vol. 1, p. 1-136 (1828a); p. 137-208 (1829); p. 209-248 (1830); p. 249-264 (1831?); p. 265-288 (1832?); p. 269336 (1834), p. 337-368 (1835?); p. 369-488 (1836) Vol. 2 p. 1-24 (1837); 25-72 (1838). G. Dufour et D' Ocagne, Paris.

Brongniart, A. T. 1828b. Prodrome d' une histoire des vegetaux fossiles. Dictionaire des sciences naturelles 57, 1-223.

Břízová, E. 2011. Pylová analýzy sedimentů u Brandova v Krušných horách, p 27-31, in Malík J. (ed.). Operativní geologická dokumentace geodynamických procesů a fenoménů v tělesech liniových staveb D8, D3 a plynovodu Gazela pro upřesnění geofaktorů horninového prostředí. Závěrečná zpráva projektu geologických prací MŽP-OOHP-32/10/GP., p. 183. MS archív ČGS, Praha. 
Cleal, C. J. Thomas, B. A. 1995. British Upper Carboniferous stratigraphy. Geological Conservation Review Series, No. 11. London (Chapman \& Hall): 295 pp.

Cílek, V. 1964. Ložisková studie Pětipesko-Žatecko 51300 085. MS Geologický průzkum, n. p. Praha, závod Dubí u Teplic. 214 pp.

Cílek, V. 1965. Nové poznatky o geologii brandovské kamenouhelné pánve v Krušných horách. Sborník Geologických věd, řada $L G, 4$, 85-102. Praha.

Corda, A. C .J. 1845. Beiträge zur Flora der Vorwelt. J. C. Calvesche Buchhandlung, Prague, $128 \mathrm{pp}$.

Cotta, B. 1854. Resultate einiger kleiner geologischer Excursionen. Neues Jahrbuch für Mineralogie, Geologie und Paläontologie. 564-566.

Crookall, R. 1966. Fossil plants of the Carboniferous rocks of Great Britain. Memoirs of the Geological Survey of Great Britain. 2nd section. Palaeontology 4(4), 355-571.

Crookall, R. 1969. Fossil plants of the Carboniferous rocks of Great Britain. Memoirs of the Geological Survey of Great Britain. 2nd section. Palaeontology 4(5), 573-791.

Crookall, R. 1970. Fossil plants of the Carboniferous rocks of Great Britain. Memoirs of the Geological Survey of Great Britain. 2nd section. Palaeontology 4(6), 793-840.

Dettmann, M. E. 1963. Upper Mesozoic microfloras from south-eastern Australia. Proc. R. Soc. Vic. 77, 1-148.

Drábková, J., Bek, J., Opluštil, S. 2004. The first compressed specimens of Spencerites (Scott) emend. and their spores Spencerisporites (Chaloner) emend. from the Upper Carboniferous (Bolsovian) of the Kladno-Rakovník and Radnice Basins, Czech Republic. Review of Paleobotany and Palynology, 130, 59-88.

Eggert, D.A., Taylor, T.N. 1966. Studies of Paleozoic ferns: on the genus Tedelea gen. nov. Palaeontographica, Abt. B 118, 52-73.

Ernst v. Warnsdorf. 1853. Über Steinkohlenschürfung bei Brandau unfern Olbernhau. Berg- und Hüttenmännisches Zeitung, 286 -288.

Feistmantel, K. 1883. Die Mittelböhmische Steinkohlenablagerung. Archiv für die Naturwissenschaftlichen Landes-Durchforschung von Böhmen, Vol. 5. Geologisches Abtheilung 3. $101 \mathrm{pp}$.
Feistmantel, O. 1873. Ueber die Steinkohlenablagerung bei Brandau im Erzgebirge. Sitzungsberichte der Königl. Böhmischen Gesselschaft der Wissenschaften in Prag, 52-54.

Geinitz, H. B. 1856. Die Steinkohlen Deutschlands und anderer Länder Europas. Vol. 1. Geologie, $74 \mathrm{pp}$.

Havlena, V. 1964. Geologie uhelných ložisek II. Nakl. ČSAV, 440 pp., Praha.

Hoffmann, U., Breitkreutz, Ch., Breiter, K., Sergeev, S., Stanek, K., Tichomirova, M. 2012. Carboniferous-Permian volcanic evolution in Central Europe-U/Pb ages of volcanic rocks in Saxony (Germany) and northern Bohemia (Czech Republic). International Journal of Earth Sciences (Geologisches Rundschau), 102, 1, 7399.

Hoth, K., Wasternack, J., Berger, H. J., Breiter, K., Mlčoch, B., Schovánek, P. (1995): Geologische Karte Erzgebirge/Vogtland 1 : 100 000.Sächsisches Landesamt für Umwelt und Geologie. Freiberg.

Jokély, J. 1857. Die geologische Beschaffenheit des Erzgebirges im Saazer Kreise in Boehmen. Jahrbuch der Geologischen Reichsanstalt Wien. 8. p. 603.

Kidston, R., Jongmans, W.J. 1917. Flora of the Carboniferous of the Netherlands and adjacent regions. Vol. I, Calamites of western Europe. Mededelingen van de Rijksopsporing van Delfstoffen, 7, 1-207 (Atlas published in 1915).

Libertín, M., Bek, J. and Drábková, J. 2014. New sphenophyllaleans from the Pennsylvanian of the Czech Republic. Review of Palaeobotany and Palynology, 200, 196-210.

Lindley, J., Hutton, W. 1932. The fossil flora of Great Britain, or figures and descriptions of the vegetable remains found in a fossil state in the country. Volume 1, 49-166. James Rigdway \& Sons, London

Lindley, J., Hutton, W. 1837. The fossil flora of Great Britain, or figures and descriptions of the vegetable remains found in a fossil state in the country. Volume 3, 123-205. James Rigdway \& Sons, London.

Malík, J. (ed.), Břízová, E., Franěk, J., Hošek, J., Hroch, T., Krupička, J., Kycl, P., Lojka, R., Mlčoch, B., Rapprich, V., Stor, T., Valečka, J., Verner, K., Vodrážka, R., Zelenka, P. 2011. Operativní geologická dokumentace geodynamických 
procesů a fenoménů v tělesech liniových staveb D8, D3 a plynovodu Gazela pro upřesnění geofaktorů horninového prostředí. - Závěrečná zpráva projektu geologických prací MŽP-OOHP32/10/GP., p. 183. MS archiv ČGS. Praha.

Meyen, S. V. 1987. Fundamentals of palaeobotany. 432 pp. Chapman \& Hall, London.

Mlčoch, B., Breiter, K., Jinochová, J. 1991. Vysvětlivky k základní geologické mapě $1: 25$ 000, 01-311 Brandov. MS Archiv ČGS. Praha.

Němejc, F. 1930. Brandovská kamenouhelná pánev (antracitová) v Rudohoří, II. část paleontologická: Rozbor fosilní květeny z brandovské uhelné pánve v Rudohoří. Palaeontographica Bohemiae, $14,30-76$.

Němejc, F. 1953. Úvod do floristické stratigrafie kamenouhelných oblastí v ČSR. Nakl. ČSAV, 173 pp., Praha.

Pešek, J., Holub, V., Jaroš, J. 2001. Geologie a ložiska svrchnopaleozoických limnických pánví České republiky. Český geologický ústav, 244 pp., Praha.

Potonié, R., Kremp, G. 1954. Die Gattungen der Paläozoischen Sporae dispersae und ihre Stratigraphie. Geol. Jahrb. 69, 111-193.

Potonié, R., Kremp, G. 1955a. Die Sporae dispersae des Ruhrkarbons, ihre Morphographie und Stratigraphie mit Ausblicken auf Arten anderer Gebiete und Zeitabschnitte. Teil I. Palaeontographica B 98, 1-136.

Potonié, R., Kremp, G. 1955b. Die Sporae dispersae des Ruhrkarbons, ihre Morphographie und Stratigraphie mit Ausblicken auf Arten anderer Gebiete und Zeitabschnitte. Teil II. Palaeontographica., Abt. B 99, 85-191.

Purkyně, C. 1926. Brandovská antracitová pánev. Věstník Státního geologického ústavu ČSR, II, 279-287. Praha

Purkyně, C. 1930. Brandovská kamenouhelná (antracitová) pánev v Rudohoří (The Carboniferous coal district of Brandov in the Rudohoří Mountains (Erzgebirge), Bohemia. I. Č́st geologická (Geology). Palaeontographica Bohemiae 14, 1-29.
Schneider, J. W., Romer, R. L. 2010. The Late Variscan Molasses (Late Carboniferous-Late Permian) of the Saxo-Thuringian Zone. In: Linnemann, U., Romer, R. L. (eds.) Pre-Mesozoic geology of Saxo-Thuringia. Schweitzerbart, pp. 323-346. Stuttgart.

Slánský, E., Valín, F. 1962. Über das Vörkommen von Tonmineralen des „Mixed -layer“. Typus in den Tonsteinen von Brandov (Erzgebirge). Věstník Ústředního ústavu Geologického, 37, 5, 365368. Praha.

Smith, A.H.V., Butterworth, M.A.1967. Miospores in the coal seams of the Carboniferousof Great Britain. Spec. Pap. Palaeont. 1, 1-324.

Stur, D. 1885. Die Carbon-Flora der Schatzlarer Schichten. Beiträge zur Kenntnis der Flora der Vorwelt II/1 Die Farne der Carbon-Flora der Schatzlarer Schichten. Abhandlungen der Geologischen Reichsanstalt (Wien), 11, 1, 1-418.

Sternberg, K. von 1823. Versuch einer geognostisch-botanischer Darstellung der Flora der Vorwelt I, 3. 1-39 pp. Ernst Brenck's, Regensburg.

Sternberg, K. von 1825 . Versuch einer geognostisch-botanischer Darstellung der Flora der Vorwelt I, 4.48 pp. Ernst Brenck's, Regensburg.

Sternberg, K. von (Presl, C. B \& Corda, A. J. coauthors) 1838. Versuch einer geognostisch-botanischer Darstellung der Flora der Vorwelt II, 7/8, 81-220. Gotlieb Hasse Söhne, Prague.

Thomas, B. A. and Brack-Hanes, S. D. 1984. A new approach to family groupings in the lycophytes. Taxon, 33, 247-255.

Thuma, F. 1920. Beitrag zur Kenntnis der Karbonschichten in Brandau im boehmischen Erzgebirge. Der Kohleninteressent, No. 19-20. p. 8-11.

Unger, F. 1850. Genera et species plantarum fossilium. 627 pp. Wilhelm Braunmuller, Wien.

Valín, F. 1970. Brandovská pánev. In Škvor, V. et al. (1970): Závěrečná zpráva o geologických výzkumech Krušných hor a Smrčin. MS Archiv ČGS. Praha.

Zelenka, C. 1926. Poznámky o některých horninách z okolí Brandova v Krušných horách. Věstník Státního geologického ústavu ČSR, II, 25-30. Praha. 